\title{
\#USGS
}

2.

Prepared incooperation with the U.S. Bureau of Reclamation

\section{Water-Quality, Instream Habitat, and the Distribution of Suckers in the Upper Lost River Watershed of Oregon and California, Summer 2018}

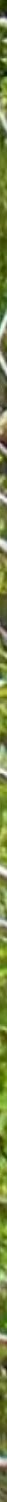


Cover. Site W03 on the North Fork of Wilow Creek, California.

Photograph by Stephen Staiger, U.S. Geological Survey, June 18, 2018. 


\section{Water Quality, Instream Habitat, and the Distribution of Suckers in the Upper Lost River Watershed of Oregon and California, Summer 2018}

By Barbara A. Martin, Summer M. Burdick, Stephen T. Staiger, and Caylen Kelsey

Prepared in cooperation with the U.S. Bureau of Reclamation

Open-File Report 2021-1077 


\section{U.S. Geological Survey, Reston, Virginia: 2021}

For more information on the USGS - the Federal source for science about the Earth, its natural and living resources, natural hazards, and the environment—visit https://www.usgs.gov or call 1-888-ASK-USGS.

For an overview of USGS information products, including maps, imagery, and publications, visit https://store.usgs.gov/.

Any use of trade, firm, or product names is for descriptive purposes only and does not imply endorsement by the U.S. Government.

Although this information product, for the most part, is in the public domain, it also may contain copyrighted materials as noted in the text. Permission to reproduce copyrighted items must be secured from the copyright owner.

Suggested citation:

Martin, B.A., Burdick, S.M., Staiger, S.T., and Kelsey, C., 2021, Water quality, instream habitat, and the distribution of suckers in the upper Lost River watershed of Oregon and California, summer 2018: U.S. Geological Survey Open-File Report 2021-1077, 29 p., https://doi.org/10.3133/ofr20211077.

ISSN 2331-1258 (online) 


\section{Contents}

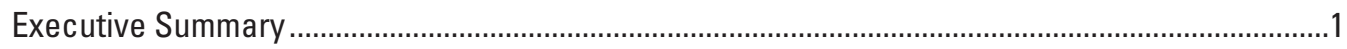

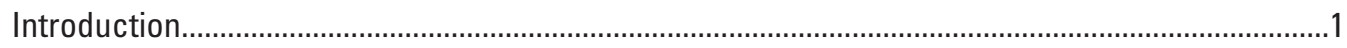

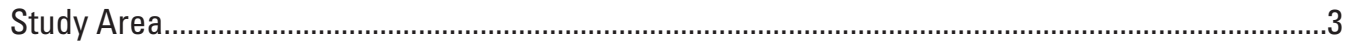

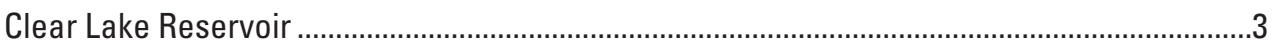

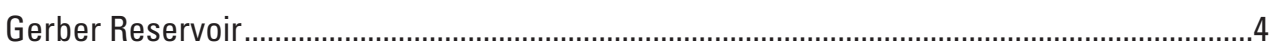

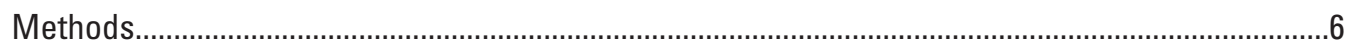

Surveys in the Clear Lake Drainage ..............................................................................

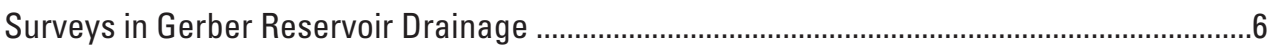

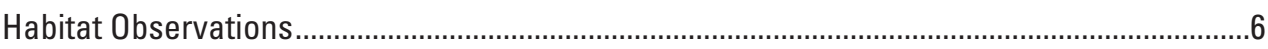

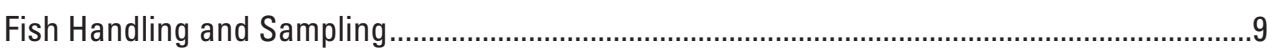

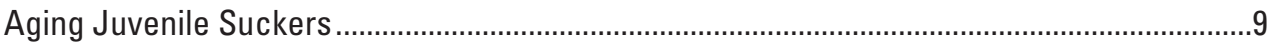

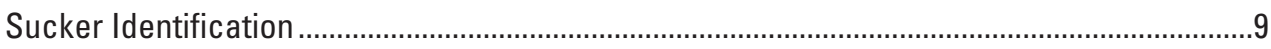

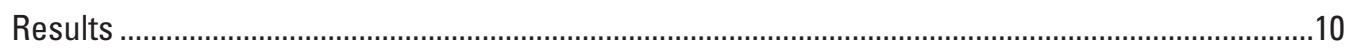

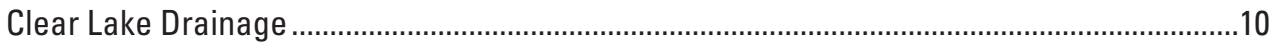

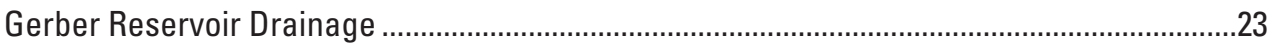

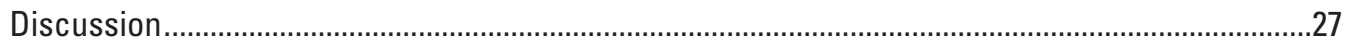

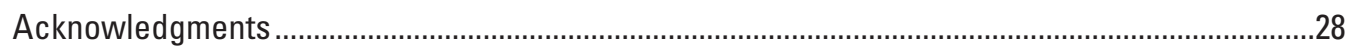

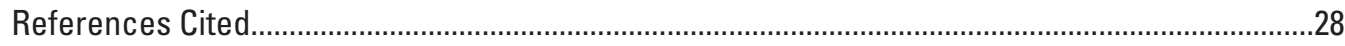

\section{Figures}

1. Overview map showing two recovery units in the Klamath Basin, Oregon ......................2

2. Overview map showing sampling sites where suckers were captured/not captured in the Clear Lake drainage, California, 2018.......................................................

3. Map showing sampled sections and where suckers were captured in the Gerber Reservoir drainage, Oregon, August 2018.........................................................

4. Expanded view of insert $A$ from figure 2 showing sampling sites identified and labeled with site designation, Clear Lake, California, 2018............................................11

5. Expanded view of insert $B$ from figure 2 showing sampling sites identified and labeled with site designation, Clear Lake, California, 2018............................................12

6. Expanded view of insert $\mathrm{C}$ from figure 2 showing sampling sites identified and labeled with site designation, Clear Lake, California, 2018.............................................13

7. Graph showing length frequency of suckers in millimeters captured in the Clear Lake drainage, California, 2018.

8. Box plot showing comparisons of water quality between sites where suckers were captured and where suckers were not captured in the Clear Lake drainage, California, 2018.

9. Graphs showing daily mean temperatures with the daily range of water temperatures at the six sites where $\mathrm{HOBO}^{\circledR}$ loggers were placed in the Clear Lake drainage, California, 2018.

10. Graphs showing length frequencies of the most abundant nontarget species captured in the Clear Lake drainage, California, 2018

11. Graph showing length frequency of suckers captured at four sample sites in the Gerber Reservoir drainage, Oregon, August 2018. 


\section{Tables}

1. Site names and sampling locations in the Clear Lake drainage, California, 2018 ............7

2. Site names and sampling locations in the Gerber Reservoir drainage, Oregon, 2018......8

3. Number of suckers captured by site, date, sampling equipment, and effort in the Clear Lake drainage, California, 2018

4. Water quality point sample measurements collected during surveys in the Clear Lake drainage, California, 2018.

5. General statistics for temperature readings in degrees Celsius from $\mathrm{HOBO} B$ loggers at six sites, two drainages, in California from June 21, 2018 through July 31, 2018

6. Numbers of fish species captured in each of the major creeks and their tributaries in the Clear Lake drainage, California, 2018

7. Number of nontarget fish measured in the Clear Lake tributaries and the mean, minimum, and maximum standard length for each species, California, 2018.

8. Water quality point sample measurements collected where suckers were captured and at the end of the survey in Gerber Reservoir drainage, Oregon, 2018.....24

9. Electrofishing effort and suckers captured in tributaries in the Gerber Reservoir drainage, Oregon, 2018

10. Locations where suckers were captured in the Gerber Reservoir drainage, Oregon, 2018 


\section{Conversion Factors}

U.S. customary units to International System of Units

\begin{tabular}{llll}
\hline & Multiply & By & To obtain \\
\hline inch (in.) & Length & \\
\hline
\end{tabular}

International System of Units to U.S. customary units

\begin{tabular}{lcl}
\hline \multicolumn{1}{c}{ Multiply } & By & To obtain \\
\hline centimeter $(\mathrm{cm})$ & 0.3937 & inch (in.) \\
millimeter $(\mathrm{mm})$ & 0.03937 & inch (in.) \\
meter $(\mathrm{m})$ & 3.281 & foot (ft) \\
kilometer $(\mathrm{km})$ & 0.6214 & mile (mi) \\
\hline & Area & square foot (ft $\left.{ }^{2}\right)$ \\
\hline square meter $\left(\mathrm{m}^{2}\right)$ & 10.76 & acre \\
square kilometer $\left(\mathrm{km}^{2}\right)$ & 0.004047 & \\
\hline cubic meter $\left(\mathrm{m}^{3}\right)$ & Volume & acre-foot (acre-ft) \\
\hline liter $(\mathrm{L})$ & 1,233 & ounce, fluid (fl. oz) \\
\hline milligram $\left(\mathrm{mg}^{2}\right)$ & 33.81402 & Mass \\
\hline
\end{tabular}

Temperature in degrees Celsius $\left({ }^{\circ} \mathrm{C}\right)$ may be converted to degrees Fahrenheit $\left({ }^{\circ} \mathrm{F}\right)$ as:

$$
{ }^{\circ} \mathrm{F}=\left(1.8 \times{ }^{\circ} \mathrm{C}\right)+32 .
$$

\section{Datums}

Horizontal coordinate information is referenced to the North American Datum of 1983 (NAD 83).

Vertical coordinate information is referenced to the Bureau of Reclamation Vertical Datum.

Elevation, as used in this report, refers to distance above the vertical datum.

\section{Supplemental Information}

Specific conductance is given in microsiemens per centimeter at 25 degrees Celsius $\left(\mu \mathrm{S} / \mathrm{cm}\right.$ at $\left.25^{\circ} \mathrm{C}\right)$.

Concentrations of chemical constituents in water are given in milligrams per liter (mg/L). 



\title{
Water Quality, Instream Habitat, and the Distribution of Suckers in the Upper Lost River Watershed of Oregon and California, Summer 2018
}

\author{
By Barbara A. Martin, Summer M. Burdick, Stephen T. Staiger, and Caylen Kelsey
}

\section{Executive Summary}

Endangered Lost River (Deltistes luxatus) and shortnose (Chasmistes brevirostris) suckers primarily use lotic habitats during the spring spawning season in the Upper Klamath Lake watershed. However, summer-time surveys of the upper Lost River watershed in 1972, 1975 and 1989-90 indicated that adults of both endangered species use tributaries of Clear Lake Reservoir (hereafter: Clear Lake) year-round. Adult shortnose suckers have also been documented to use tributaries of Gerber Reservoir year-round. We surveyed the tributaries of Clear Lake and Gerber Reservoir to provide up-to-date information on the timing, distribution, and habitat use within the upper Lost River drainage by these two endangered sucker species.

Contrary to previous studies, this study did not capture any Lost River suckers in the Clear Lake tributaries. Genetics samples from suckers collected during this study were used to verify that no Lost River suckers were captured. At the time of this study, genetics could not identify the differences between shortnose and the non-endangered Klamath largescale suckers (Catostomus snyderi), therefore, morphology was used to separate these two species. Furthermore, the shortnose suckers and the Klamath largescale suckers documented in the upper Lost River drainage are more similar to Klamath largescale suckers than shortnose suckers that exist in the Upper Klamath Lake recovery unit. Therefore, the suckers we documented during our surveys were most likely Klamath largescale suckers.

We captured suckers, age- 0 to age- 9 , in the Clear Lake tributaries within stream pools and flooded meadows behind water retention structures. However, no suckers were collected in small reservoirs sampled upstream of Clear Lake. Suckers were found in habitats with mud and fine substrate at depths of 0.5-3.0 meters, with most captured at 1.0 meter or less. Suckers co-occurred with nonnative species, which were more abundant in our survey than in previous surveys in the tributaries to Clear Lake.

Gerber Reservoir tributaries yielded more suckers per unit effort than Clear Lake tributaries. All suckers captured in the tributaries of Gerber Reservoir were identified as Klamath Largescale suckers. The suckers in tributaries to Gerber Reservoir were collected in similar habitat as those in Clear Lake tributaries and were age- 0 to age- 6 .

\section{Introduction}

Lost River (Deltistes luxatus) and shortnose (Chasmistes brevirostris) suckers are endemic to the Upper Klamath River Basin and were listed as endangered in 1988 (U.S. Fish and Wildlife Service [USFWS], 1988). Currently, the largest populations are found in Upper Klamath Lake, Clear Lake reservoir (hereafter: Clear Lake), and their tributaries (fig. 1). The U.S. Fish and Wildlife Service has designated two recovery units, the Upper Klamath Lake Unit and the Lost River Basin Unit, in their recovery plan for the Lost River and shortnose suckers (USFWS, 2013). The Upper Klamath Lake Unit supports the majority of the Lost River and shortnose sucker populations and encompasses Upper Klamath Lake, its tributaries, and reservoirs along the Klamath River. The Lost River Basin Unit appears to mainly support remnant populations, highly hybridized populations, or both, and it encompasses the Lost River and its associated lakes and reservoirs (USFWS, 2013). Clear Lake and Geber Reservoirs and their tributaries were the focus of this study because they are the main management areas and the only designated critical habitat (USFWS, 2012) in the Lost River Basin (fig. 1). 


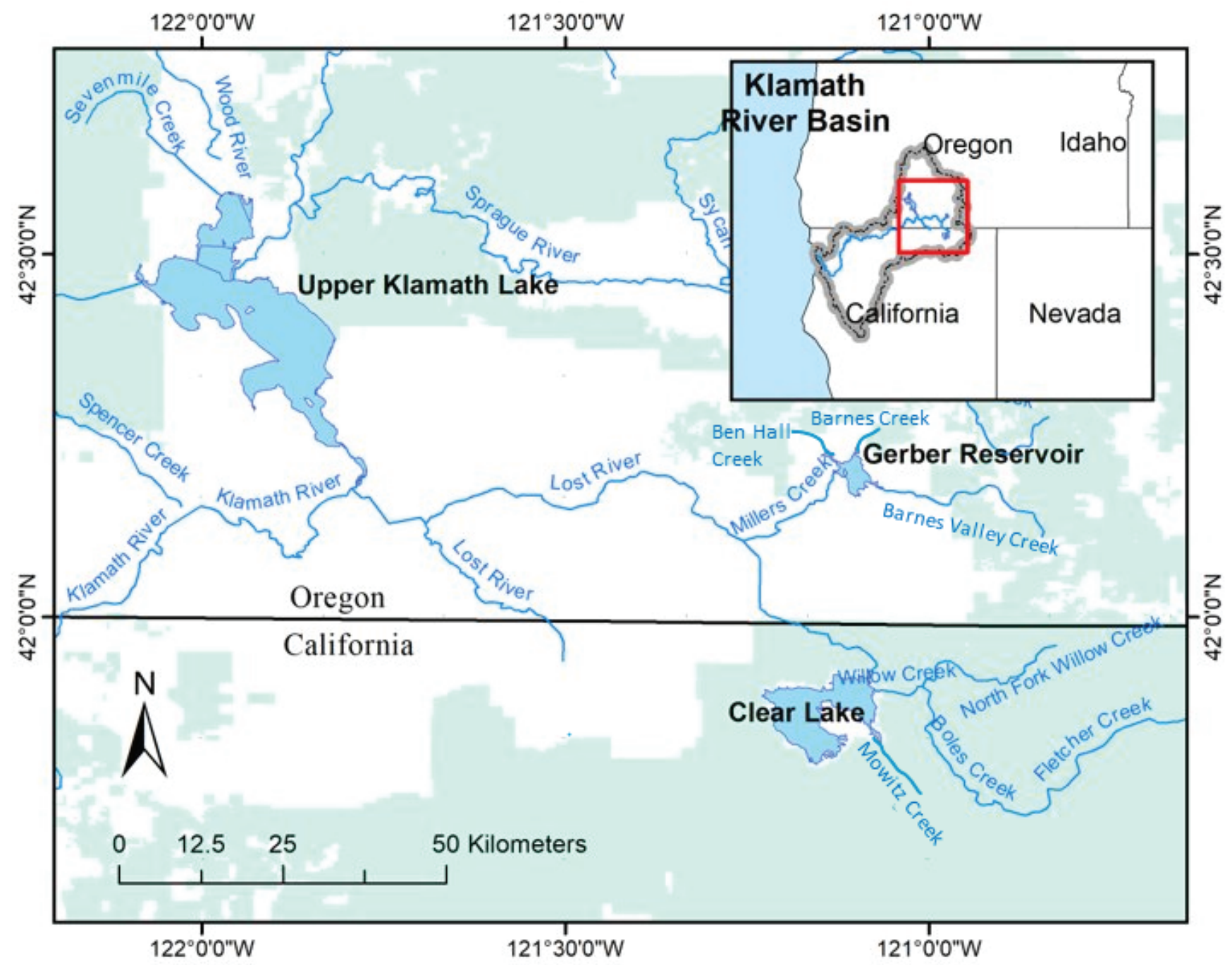

Figure 1. Two recovery units in the Klamath Basin, Oregon. Green shaded areas represent the U.S. Forest Service's Fremont-Winema National Forest in Oregon and the Modoc National Forest, California.

Lost River and shortnose suckers are long-lived catostomids that primarily occupy lakes during the summer months and make spawning migrations into lotic habitats in the spring, beginning at about age-4 to age-7 (Hewitt and others, 2015). In the Clear Lake drainage, spawning migrations start when these tributary waters exceed about 6 degrees Celsius $\left({ }^{\circ} \mathrm{C}\right)$ with spawning generally occurring from February to April (Hewitt and Hayes, 2013; Hewitt and others, 2021). In the Upper Klamath Lake drainage spawning is not triggered until temperatures reach $10^{\circ} \mathrm{C}$, and it is unknown what temperatures trigger a migration in the Gerber Reservoir drainage. At least some Clear Lake sucker larvae out-migrate from Willow Creek in the spring, probably beginning in early April and into May (Perkins and Scoppettone 1996; Sutphin and Tyler, 2016). Buettner and Scoppettone (1991) documented juvenile suckers throughout the Clear Lake drainage during the summer months. This observation indicated that some suckers were rearing for 1 year or more in the tributaries of
Clear Lake. However, it was not clear from their study if rearing in tributaries was a life history strategy for suckers, or an occasional occurrence resultant of stranding in pools as water levels in the streams decline causing seasonal fragmentation of habitats. Although, Buettner and Scoppettone (1991) referred to these suckers as shortnose, they could have been Klamath largescale suckers.

Information on the distribution of suckers within these reaches and timing of habitat use by life stage is limited to several previous survey efforts in the Clear Lake drainage within the Modoc National Forest during the summers of 1972, 1975, and 1989-90 (Sonnevil, 1972; Koch and others, 1975; Buettner and Scoppettone, 1991). These surveys used a variety of sampling techniques to determine sucker distribution, relative apparent abundance, habitat, and species assemblages in the Clear Lake tributaries. Limited numbers of suckers were captured during the surveys, with the majority of older suckers captured in lacustrine habitats, while many 
of the young of year suckers were captured in the creeks. In April of 1973, Koch and Contreras (1973) captured reproductively ripe Lost River and shortnose suckers in Willow Creek, but did not collect any suckers in Boles Creek (fig. 1). These studies found low species diversity and determined that tui chub (Siphateles bicolor) was the dominant species. Koch and others (1975) noted that overgrazing was a major problem leading to streambank and soil instability at all sites, possibly affecting suckers use of the habitat. Buettner and Scoppettone (1991) indicated that major impacts to sucker habitat included cattle grazing, reservoir drawdown and proliferation of exotic species.

The main objective for the 2018 fish survey in Clear Lake and Gerber Reservoir drainages was to update distributional and age structure information of the two endangered suckers. Habitat characteristics associated with the presence of suckers, including basic water-quality conditions were also described. Furthermore, species assemblages in the tributaries of Clear Lake were documented for comparison with information collected in previous surveys.

\section{Study Area}

\section{Clear Lake Reservoir}

Clear Lake, located in Modoc County, California, is primarily fed by waters that flow through the U.S. Forest Service's Modoc National Forest. Willow Creek is the main tributary to Clear Lake and enters near the dam at the lake's outlet. Prior to the construction of the dam, Mowitz Creek appears to have been the primary tributary because Willow Creek entered the Lost River downstream of the historical lake (Buettner and Scoppettone, 1991). The two major tributaries of Willow Creek are: (1) the North Fork Willow Creek, that drains the northern part of the watershed, and (2) Boles Creek, which drains the southern part of the watershed. These two creeks join to form Willow Creek about $8 \mathrm{~km}$ before it enters the reservoir. The area around the lake is rocky with sagebrush (Artemesia sp.) steppe plant communities and western juniper (Juniperus occidentalis), whereas the upper watershed is a ponderosa pine (Pinus ponderosa) forest (Buettner and Scoppettone, 1991).

The headwaters of North Fork Willow Creek are located in the U.S. Forest Service's Fremont-Winema National Forest, Oregon. At the headwaters, the creek passes through privately and publicly owned pasture lands and then enters an area containing large lava rockslides. North Fork Willow Creek descends rapidly in the area containing the lava rockslides, which form steep rapids during the wet season (approximately February-April). During the dry season in which our sampling took place, water flows completely sub-surface through these slides. Downstream of these slides, North Fork Willow Creek flows through several narrow canyons that are separated by large man-made meadows. At the downstream end of the meadows, dams are seasonally closed in order to pool water and create forage for livestock. From the headwaters to the mouth of Clear Lake, the combination of North Fork Willow Creek and Willow Creek flows 34.6 kilometers (km) and loses 284 meters (m) of elevation. Four Mile creek is a major tributary of North Fork Willow Creek. The headwaters of Four Mile Creek are in Four Mile Reservoir, a small impoundment that is primarily fed by snow melt (fig. 2). Wildhorse Creek is a tributary to Four Mile Creek which joins it at Reservoir A. Wildhorse Creek's headwaters are in Wildhorse Reservoir approximately $2 \mathrm{~km}$ above the confluence with Four Mile Creek.

The Boles Creek watershed is in the Modoc National Forest, California. Fletcher Creek is the largest tributary to Boles Creek, surrounded by dense Ponderosa pine at its headwaters, whereas the lower elevations are surrounded by meadows. Fletcher Creek has several smaller tributaries (many of which are unnamed). Two of the larger tributaries are Little Willow Creek and Mosquito Creek (fig. 2). There are several reservoirs associated with Fletcher Creek, including Avanzino, Bayley, Deer Hill, Janes, and Telephone Flat. The confluence of Fletcher and Boles creeks are in an upper plateau area of the forest at Boles Meadow. Boles Creek, a low gradient stream that loses $121 \mathrm{~m}$ of elevation over the $27.5 \mathrm{~km}$ from Boles Meadow to the confluence with Willow Creek, passes through a lava canyon in its upper reaches before descending to meadow habitat. Boles Creek contains many large pools, disconnected during the summer months, with a substrate of large igneous boulders.

Mowitz Creek is a low gradient stream consisting of small pools disconnected during summer low flows (fig. 2). The length of the creek is $12.5 \mathrm{~km}$, over which the total elevation loss is only $17 \mathrm{~m}$. This creek is within a dry meadow, composed mainly of boulder substrate with minimal submerged vegetation, and is clear enough to see the bottom. 


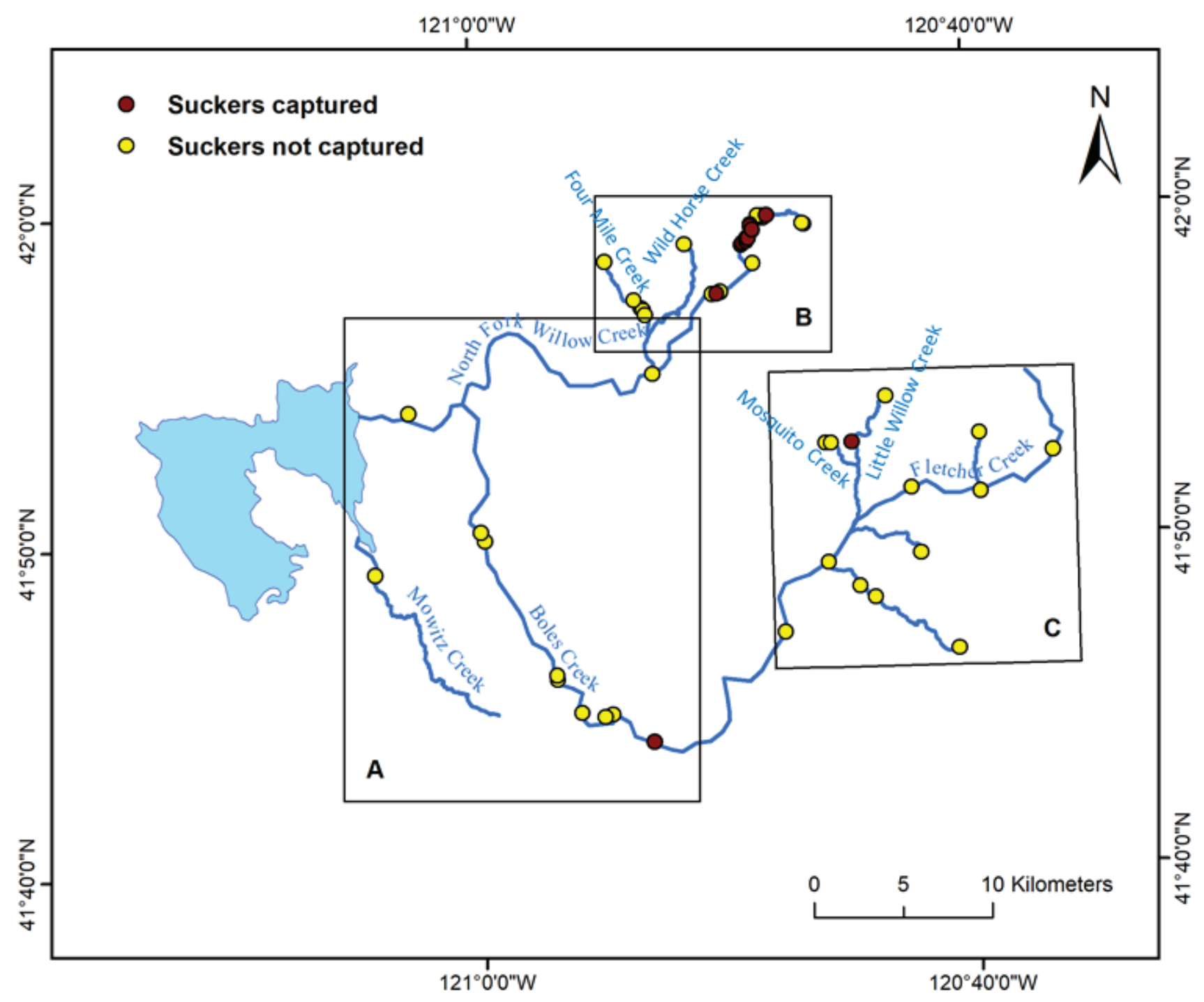

Figure 2. Sampling sites where suckers were captured/not captured in the Clear Lake drainage, California, 2018.

\section{Gerber Reservoir}

Gerber Reservoir is located in Klamath County, Oregon and is primarily fed by Barnes Valley Creek from the southeast, Ben Hall Creek from the northwest, and Barnes Creek from the northeast (fig. 1). The outflow of the reservoir is through Millers Creek to the southwest. Although suckers were found in Ben Hall Creek in the 1990s (Mark Buettner, Klamath Tribes, written commun., Feb. 16, 2021, provided Bureau of Land Management, unpub. data), the current study focused on Barnes Valley Creek and its tributaries because this habitat is on public lands and suckers were recently documented there (Bureau of Land Management, 2014). Barnes Valley Creek and its tributaries are mostly in the FremontWinema National Forest, Oregon, with the rest located on
Bureau of Land Management lands from the forest boundary to Gerber Reservoir (Bureau of Land Management, 1992). Lapham Creek (fig. 3) is a major tributary surrounded by meadows with alders (Alnus sp.), rush sage (Salvia sp.), and ponderosa pine upslope that joins the headwaters of the Barnes Valley Creek in the Barnes Valley. From the headwaters, Barnes Valley Creek flows through a steep-walled basalt canyon surrounded by sage and juniper before entering meadow habitat. Long Branch Creek (fig. 3) joins Barnes Valley Creek approximately $2.5 \mathrm{~km}$ before Barnes Valley Creek enters Gerber Reservoir. Long Branch Creek's headwaters are at Long Branch Spring, with the creek fed by several springs along its decent. The upper watershed is composed mainly of sage and juniper while the lower is mainly meadows. 

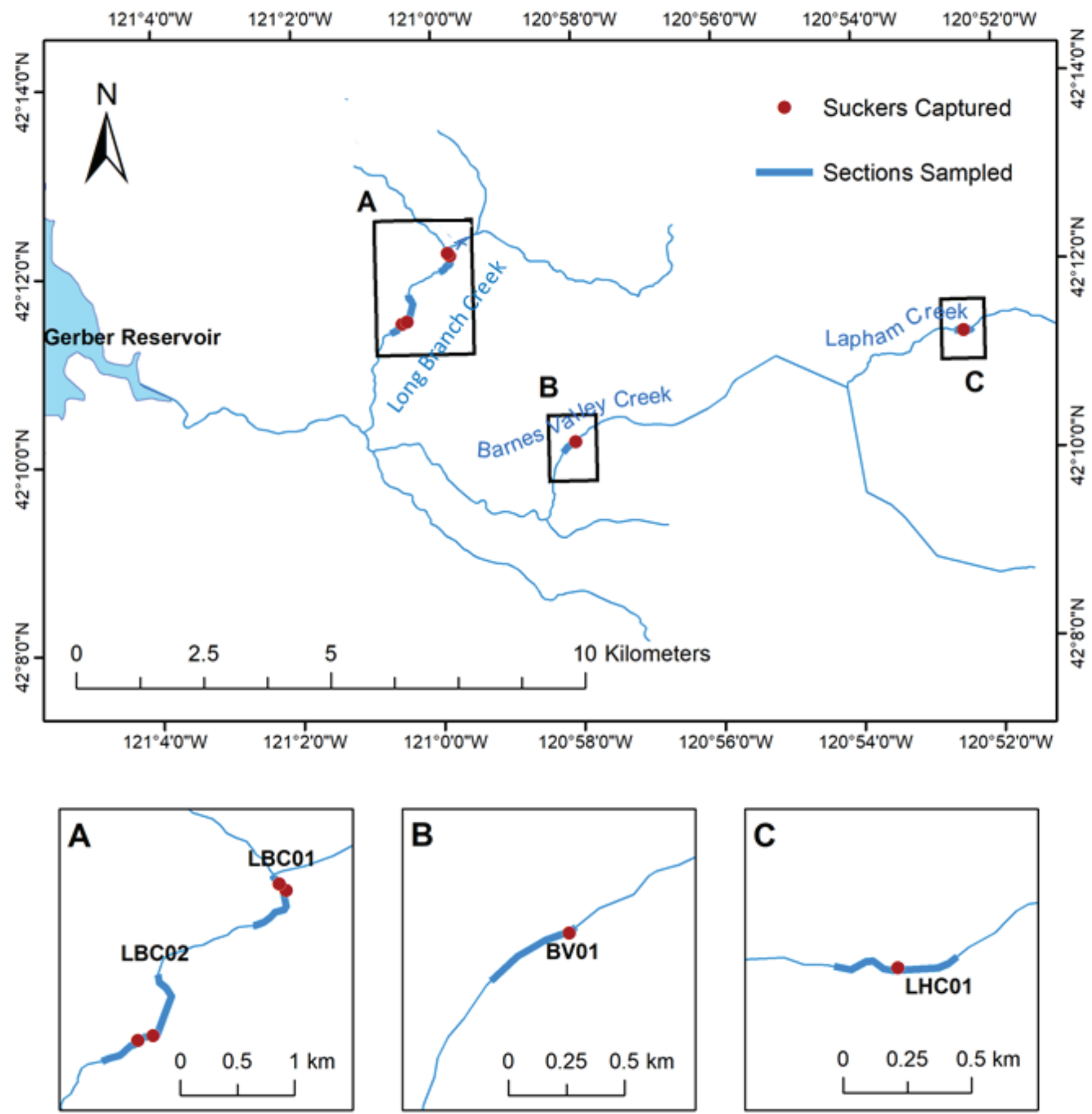

Figure 3. Sampled sections and where suckers were captured in the Gerber Reservoir drainage, Oregon, August 2018. Insets A-C within this figure show expanded views. 


\section{Methods}

\section{Surveys in the Clear Lake Drainage}

Clear Lake tributaries were surveyed for one week during each month from June through September 2018. A total of 47 sites were visited during this period (table 1). Forty-six of these sites were sampled independently, while W13 was only sampled as part of a sampling area that was composed of a reach between two sampling sites (W13-W10). An additional, 3 reaches were sampled from sampling site to sampling site (LVD01-LVD04, LVD04-W01, and W06-W10). Sample sites were selected to provide a wide distribution over available habitat and include various habitats throughout the drainage. Site selection was based on accessibility. Sample locations extended from near the mouth of Willow Creek to upstream of the previously documented sucker habitat (Koch and others, 1975; Buettner and Scoppettone, 1991) and on Mowitz Creek. Half of the sample locations were in the northern part of the drainage area, along the North Fork Willow Creek and its tributaries, and the other half in the southern part of the drainage area, that encompassed Fletcher, Boles, and Mowitz creeks and their tributaries. Most sites were visited one time during the 4-month study. A quarter of the more easily accessible sites were designated for four repeat visits to document potential monthly changes in sucker abundance. However, because of heavy smoke from wildfires during August and September 2018 these sites were only visited twice.

We used a variety of collection equipment to sample the wide range of habitats in the Clear Lake drainage, with limited available effort. Two ground crews went out each sampling event. Sampling methods used to capture suckers included electrofishing, trap nets, and trammel nets. There was no defined area (in square meters) sampled, instead, electrofishing surveys were limited to 15 minutes for each site to maximize number of sites sampled. Stream runs were sampled for close to the 15-minute limit while stream pools were sampled for much less time with duration dependent on the size of the pool. Smith \& Root LR-24 electrofisherTM backpacks with an 11-inch stainless-steel ring electrode were used to capture fish. Power settings were initially set to standardize power output. However, because of poor performance at the first sampling site, settings were later altered to meet a desired fish response of lightly stunned. Power output settings on the electrofisher ranged from 38 to 325 watts. These calculations were based on electrofisher volts settings multiplied by the amp output. Duty cycle ranged from 25 to 40 percent. Shocking was done with at least one netter for each site. Total duration of shocking time, in seconds, was recorded after each effort at each site. Trap and trammel nets were set in areas where it was too deep to wade in the stream and therefore too deep to use a backpack electrofisher. Set times for trap nets did not exceed 24 hours and set times for trammel nets did not exceed three hours. Set and pull times were recorded for each net set. The number of nets set was determined in the field based on width, depth, and length of the stream and accessibility to the sites, and did not exceed two nets per sample site. The trap nets used were rectangular with mouth dimensions of $0.61 \times 0.91 \mathrm{~m}$, a 10 -m-lead, and three internal fykes. Two anchors were tied at each end to prevent the trap from collapsing. Each trap net was set across the current, and if the width of the stream was less than $10 \mathrm{~m}$, the nets were set at an angle. Trammel nets used were $15 \mathrm{~m}$ in length, $1.8-\mathrm{m}$ tall with two outer panels $(30$-centimeter [cm] bar mesh), an inner panel (3.8-cm bar mesh), a foam core float line, and a lead core bottom line. Trammel nets were only used on four occasions during the June sampling event because of their ineffectiveness at capturing juvenile suckers.

\section{Surveys in Gerber Reservoir Drainage}

We made four single day trips to the Gerber Reservoir drainage from August 20 through 31, 2018. Sampling was conducted at Barnes Valley Creek and two of its tributaries, Lapham Creek and Long Branch Creek. On each date a different section of a creek was sampled for a total of four sampling sections (table 2).

A single ground crew went out each sampling event. Electrofishing was the only sampling method used due to the more continuous nature of the streams in the Gerber Reservoir drainage. A Smith \& Root LR-24 electrofisher ${ }^{\mathrm{TM}}$ backpack with an 11-inch stainless-steel ring electrode was used to capture fish. As in Clear Lake Tributaries, wattage settings were altered to meet a desired fish response of lightly stunned. Power output settings on the electrofisher ranged from 84 to 240 watts. These calculations were based on electrofisher volts settings multiplied by the amp output. The duty cycle ranged from 30 to 40 percent. Shocking was done with at least one netter for each site. The duration of effort was recorded in seconds per survey per site. We started surveys at road crossings then worked continuously upstream or downstream, stopping when suckers were encountered. The exact locations of suckers within each reach were documented and habitat characteristics were recorded when suckers were captured. Bycatch was not recorded during these surveys.

\section{Habitat Observations}

The habitat at each site was characterized and described in field notes. In the Clear Lake drainage, where pools were often discontinuous, max pool depth, width, and length were estimated. Bank suitability and height of incised channel were also described in field notes. Signs of grazing and number of livestock were noted. Stream wetted width and max depth were measured at each site. Substrate type, submerged vegetation, and woody debris within sites were characterized based on type and abundance. Submerged vegetation was classified as none, moderate (1-15 percent), and a lot (>20 percent), while number of pieces of woody debris greater than $10 \mathrm{~cm}$ in diameter was counted. 
Table 1. Site names and sampling locations in the Clear Lake drainage, California, 2018.

[Coordinates given are the starting location for the sample site. Unless otherwise indicated, a single pool was sampled at each site. Waterbody: N.F., North Fork. Elevation: m, meter]

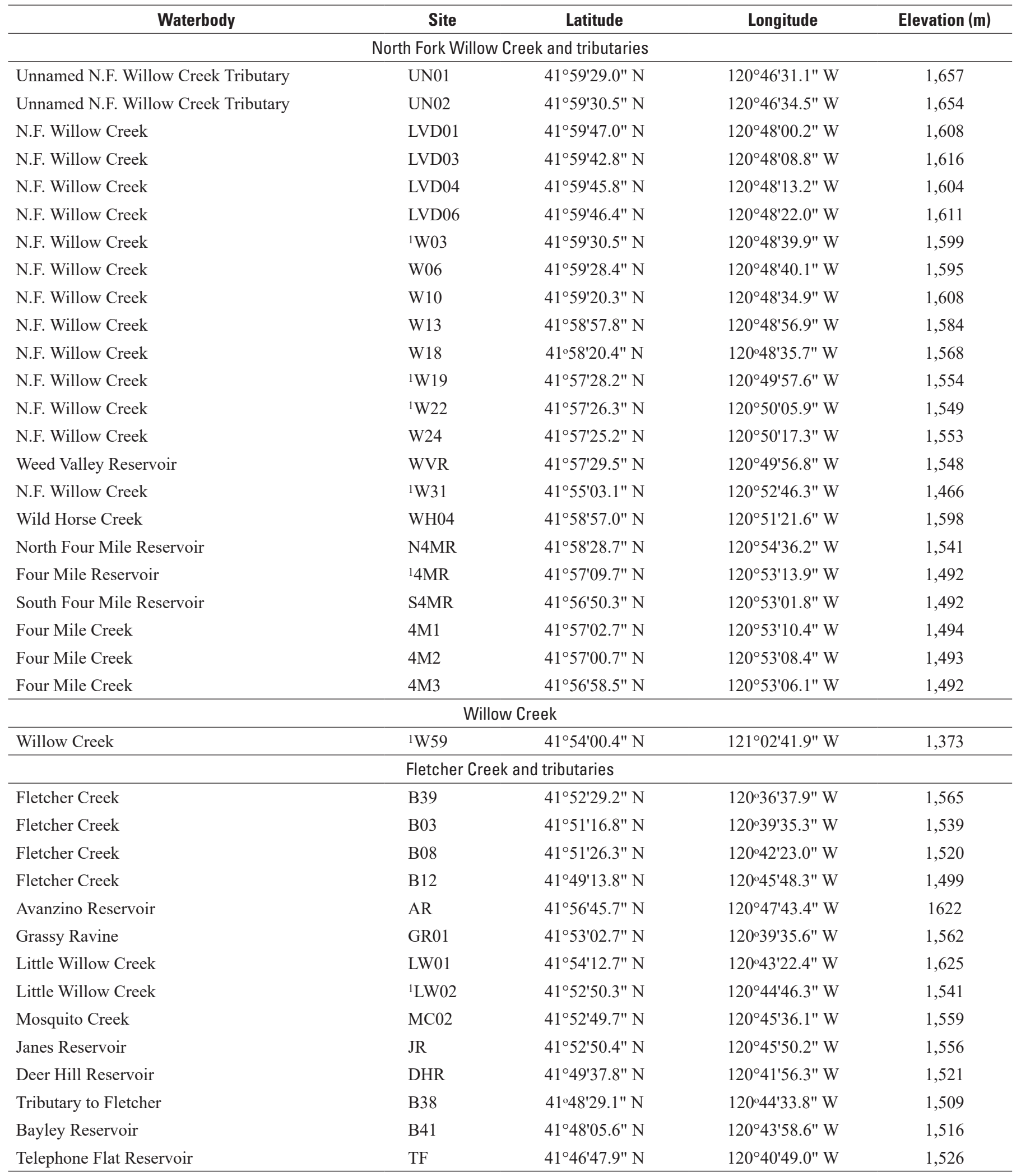


Table 1. Site names and sampling locations in the Clear Lake drainage, California, 2018._Continued

[Coordinates given are the starting location for the sample site. Unless otherwise indicated, a single pool was sampled at each site. Waterbody: N.F., North Fork. Elevation: m, meter]

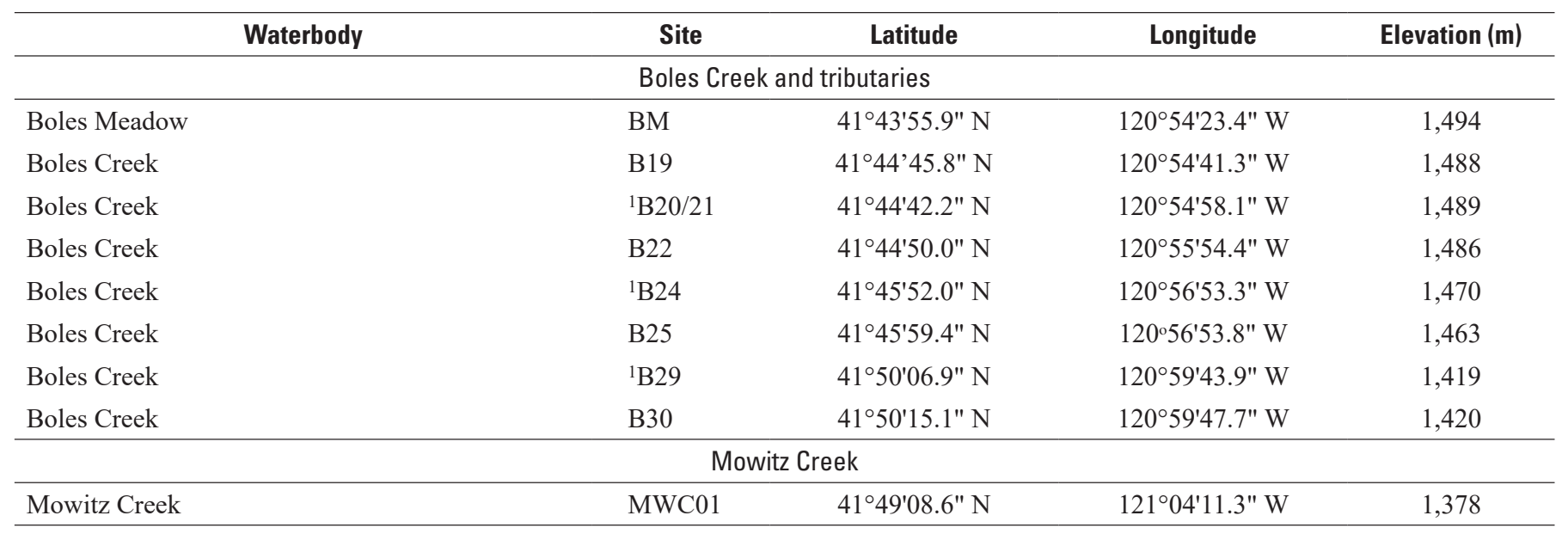

${ }^{1}$ These sites were sampled twice.

Table 2. Site names and sampling locations in the Gerber Reservoir drainage, Oregon, 2018.

[Coordinates given are the starting and ending location for the sample sites, denoted by time. Date: mm-dd-yyyy, month-day-year; Time: hh:mm, hours: minutes. Elevation: m, meter]

\begin{tabular}{|c|c|c|c|c|c|c|c|}
\hline Creek & $\begin{array}{c}\text { Site } \\
\text { name }\end{array}$ & $\begin{array}{c}\text { Date } \\
\text { (mm-dd-yyyy) }\end{array}$ & Period & $\begin{array}{c}\text { Time } \\
\text { (hh:mm) }\end{array}$ & Latitude & Longitude & $\begin{array}{l}\text { Elevation } \\
\text { (m) }\end{array}$ \\
\hline Barnes Valley Creek & BVC01 & $08-20-2018$ & Start & 09:46 & $42^{\circ} 10^{\prime} 02.9^{\prime \prime} \mathrm{N}$ & $120^{\circ} 58^{\prime} 13.9^{\prime \prime} \mathrm{W}$ & 1,567 \\
\hline \multirow[t]{2}{*}{ Lapham Creek } & LHC01 & $08-31-2018$ & Start & $09: 25$ & $42^{\circ} 11^{\prime} 16.3^{\prime \prime} \mathrm{N}$ & $120^{\circ} 52^{\prime} 35.6^{\prime \prime} \mathrm{W}$ & 1,585 \\
\hline & & & End & $12: 00$ & $42^{\circ} 11^{\prime} 16.4^{\prime \prime} \mathrm{N}$ & $120^{\circ} 52^{\prime} 20.5^{\prime \prime} \mathrm{W}$ & 1,594 \\
\hline \multirow[t]{2}{*}{ Long Branch Creek } & LBC02 & $08-22-2018$ & Start & $09: 35$ & $42^{\circ} 11^{\prime} 21.4 " \mathrm{~N}$ & $121^{\circ} 00^{\prime} 39.6^{\prime \prime} \mathrm{W}$ & 1,556 \\
\hline & & & End & $12: 30$ & $42^{\circ} 11^{\prime} 45.8^{\prime \prime} \mathrm{N}$ & $121^{\circ} 00^{\prime} 23.0^{\prime \prime} \mathrm{W}$ & 1,569 \\
\hline
\end{tabular}

Water quality was measured in both the Clear Lake and Gerber Reservoir drainages to understand habitat conditions correlated with sucker detections. Water temperature was monitored, using $\mathrm{HOBO}^{\circledR}$ temperature loggers, hourly from mid-June to mid-September at six sites (W03, W31, W59, $\mathrm{B} 12$, B24, and B29) in the Clear Lake drainage. The $\mathrm{HOBO}^{\circledR}$ loggers were placed throughout the watershed with two in North Fork Willow Creek, one in Willow Creek, two in Boles Creek, and one in Fletcher Creek. Due to receding waters, the three $\mathrm{HOBO}^{\circledR}$ loggers, located in the Boles Creek watershed were no longer immersed by the end of the study. The last reading at all six sites occurred July 31,2018 . Five of the six sites where $\mathrm{HOBO}^{\circledR}$ loggers were placed (excluding B12) were sites that were visited on two occasions (table 1). Point samples of dissolved oxygen, $\mathrm{pH}$, temperature, and specific conductance were collected just prior to each survey at all sites sampled for fish using a YSI 600 XLM sonde coupled with a YSI 650 Multiparameter Display System. In the Clear Lake drainage these point samples were collected once per site visit, whereas in the Gerber Reservoir drainage point samples were collected at the beginning and end of each survey and at locations where suckers were captured. Prior to each field trip, sondes were calibrated per manufactures instructions. After arriving at a site, the sonde was placed in water that at a minimum was deep enough so that all probes were submerged. Data were recorded after temperature, dissolved oxygen, specific conductance, and $\mathrm{pH}$ values stabilized. Dissolved oxygen readings were converted to percent saturation using the equations from Benson and Krause (1980; 1984). Percent saturation was calculated because it incorporates variation due to water temperature and atmospheric pressure. We used an elevation adjustment to approximate the effect of barometric pressure at the given altitude of each site (Bowie and others, 1985). 


\section{Fish Handling and Sampling}

To document size, age, and species composition of suckers throughout the Clear Lake and Gerber Reservoir drainages, we measured standard length (SL) of captured suckers and collected several biological samples. To estimate fish age, the leading left pectoral fin ray was removed at the proximal end of suckers measuring 50 millimeters $(\mathrm{mm}) \mathrm{SL}$ or greater. Using clean scissors, tissue samples for genetics were taken from the upper lobe of the caudal fin from all suckers and then covered with wax paper and placed within coin envelopes for drying.

Passive integrated transponder (PIT) tags were implanted in some suckers to facilitate future monitoring of within stream movements. Suckers were scanned for previously implanted PIT tags using the Biomark ${ }^{\circledR}$ Portable Transceiver System Model 2001F-ISO. Untagged suckers greater than 70 $\mathrm{mm}$ SL were injected with a 135 kilohertz $12 \mathrm{~mm}$ PIT tag ventrally through the body cavity. To improve sucker post tagging survival, suckers were only administered a PIT tag when water temperatures were less than $20^{\circ} \mathrm{C}$. Recaptures, as determined by the presence of a PIT tag, were recorded and all suckers were photographed. Fish were released at the site of capture.

We summarized the prevalence and intensity of external afflictions on all captured suckers. Emaciation, deformities, macro parasites, petechial skin hemorrhaging, and gill abnormalities were systematically recorded. Other abnormalities and afflictions were noted when they were observed. We paid close attention to those afflictions that are common or potentially associated with mortality (Markle and others, 2014; Burdick and others, 2015). These included petechial hemorrhaging of the skin, opercular deformities, black spots (presumed to be encysted metacercariae of Bolbophorus sp.), and the macro parasite Lernaea sp. These afflictions are noted on suckers captured in Clear Lake and Upper Klamath Lake during yearly sampling and therefore were recorded to allow comparison among water bodies.

To identify patterns in cohabitation among fishes and potential competition with or predation of suckers by other fishes, we recorded data on the location, size, and abundance of non-sucker fishes collected during surveys in Clear Lake tributaries. We counted or estimated the number of non-sucker fishes captured during each survey effort. Nontarget fish were estimated when there were too many fish to count in a reasonable amount of time without potentially harming the fish. In these instances, fish were counted from a full aquarium net and then the number of nets were counted. The number of nontarget fish was estimated through extrapolation on these occasions. Standard length was measured for a random selection of five fish of each fish species captured in each survey.

\section{Aging Juvenile Suckers}

To age the suckers, fin rays were mounted in epoxy, sectioned, and viewed by two experienced readers under magnification using transmitted light (Quist and others, 2012). The number of annuli was first determined in blind reads, with each reader unaware of the other's annuli count. The differences between annuli counts of the same structures were summarized to examine aging precision. When both readers agreed on a number of annuli, that number was presumed to be the correct age and was used in analyses. If there was disagreement in the annuli count of two or fewer, the two readers viewed the structure together and came to a consensus or a third reader acted as a tie breaker. The quality of our aging techniques was reviewed in Burdick and others (2015).

\section{Sucker Identification}

In the Clear Lake drainage, suckers were identified to species using genetic identification techniques described by Hoy and Ostberg (2015). A small piece of dried tissue (about 2 $\mathrm{mm}^{2}$ ) from the caudal fin of each sucker was used for genetic identification to taxa. The method used can only distinguish Lost River suckers from shortnose and Klamath largescale suckers (Catostomus snyderi), and cannot distinguish between shortnose suckers and Klamath largescale suckers. Eighteen nuclear DNA TaqMan ${ }^{\circledR}$ assays were used to differentiate the species based on single nucleotide polymorphisms (SNPs) (Hoy and Ostberg, 2015). A mitochondrial DNA (mtDNA) $\mathrm{TaqMan}^{\circledR}$ assay also was applied to identify the maternal lineage (Lost River or other sucker) for each individual (Hoy and Ostberg, 2015). Using the program STRUCTURE, version 2.3 (Pritchard and others, 2000; Evanno and others, 2005), we probabilistically assigned fish to one of two species categories (Lost River sucker or other sucker). For data summary purposes, we categorized suckers having a probability of assignment as a Lost River sucker of greater than or equal to 0.95 a Lost River sucker, those with a probability of assignment as a Lost River sucker of less than or equal to 0.05 a shortnose/ Klamath largescale sucker, and fish with probabilities between these two values, as uncertain species assignment (Burdick and others, 2016). Suckers were also identified using external morphological characteristics; however, these identifications did not use meristics or morphometrics, which are a lethal method that is more accurate in identifying the different sucker species (Markle and others, 2005). Non-lethal methods are not available to accurately determine if fish that are less than about $200 \mathrm{~mm}$ SL are shortnose or Klamath largescale suckers, consequently smaller non-Lost River suckers were not identified to species. 
In the Gerber Reservoir drainage, only morphological identifications were conducted. Historically there have not been any Lost River suckers in the Gerber Reservoir drainage, only shortnose and Klamath largescale suckers. Genetics were not used because genetic techniques that were available at the time of this study could not distinguish shortnose suckers from Klamath largescale suckers.

\section{Results}

\section{Clear Lake Drainage}

Suckers were not abundant during our survey with only 76 suckers captured during 8 of the 74 (11 percent) sampling events in Clear Lake tributaries (figs. 2, 4-6; table 3). Three of the 76 suckers were identified with PIT tags as recaptures during the study; therefore, at most 73 unique individuals were captured from June through September 2018. The three recaptured individuals were initially captured by electrofishing and recaptured the next day at the same site (W06) in trap nets (fig. 5). The majority of suckers were captured in trap nets ( 80 percent), with 56 of the suckers captured at the Boles Meadow (BM) site (fig. 4). The suckers captured from BM were congregated above a water retention structure. Fourteen suckers were captured using electrofishing, mainly in the upper parts of the North Fork Willow Creek (fig. 5; table 3).

Size of suckers in the Clear Lake drainage varied depending on capture location. The majority of suckers captured (63 fish; 86 percent) were age- 0 to age- 3 and were less than $200 \mathrm{~mm}$ SL (fig. 7). The remaining 10 suckers were greater than $200 \mathrm{~mm}$ SL and were age-4 to age-9. All suckers captured in Boles Meadow were $72 \mathrm{~mm}$ SL or less. The majority of suckers captured in North Fork Willow Creek (15 fish; 94 percent) were greater than or equal to $92 \mathrm{~mm} \mathrm{SL}$ with the remaining sucker $52 \mathrm{~mm}$ SL. The smallest sucker in North Fork Willow Creek (52 mm SL) was the farthest upstream sucker captured (LVD01). We found that the bigger $(\geq 267 \mathrm{~mm}$ SL) and older fish (age-4 to age-9) were captured at W06, W06-W10, and W13-W10 (table 3) in the upper part of North Fork Willow Creek. Age-1 juveniles (92-119 mm SL) were found at W13-W10 and W22. The only sucker found in Little Willow Creek (LW02), a tributary to Fletcher Creek, was age-3 and was $187 \mathrm{~mm} \mathrm{SL} \mathrm{(fig.} \mathrm{7;} \mathrm{table} \mathrm{3).}$

Suckers in the Clear Lake drainage were identified as shortnose or Klamath largescale suckers. Suckers larger than $200 \mathrm{~mm}$ SL ( $n=10)$ were identified using morphological characteristics and species was confirmed using genetics. Suckers less than $200 \mathrm{~mm}$ SL were not identified to species, but genetics confirmed that they were shortnose or Klamath largescale suckers, rather than Lost River suckers. Larger and older fish captured in the upper parts of North Fork Willow Creek (sites W06, W06-W10, and W13-W10 [fig. 5; table 3]) were morphologically identified as Klamath largescale $(n=8)$ or shortnose $(n=2)$ suckers. All suckers appeared healthy with the exception of two individuals, both from the upper part of North Fork Willow Creek, each having one or two copepod parasites (Lernaea sp.). There were no other signs of external afflictions on captured suckers.

The habitat was similar at all locations, regardless of suckers captured. Suckers were mostly present in runs or pools with fine substrate and moderate submerged vegetation in depths ranging from 0.5 to $3.0 \mathrm{~m}$. The riparian vegetation was generally meadow habitat with sedges and rushes lining the stream banks. At sites where suckers were captured (and most other sites), livestock were not present at the time of sampling, but there were recent signs of livestock. However, at site W13-10 cattle appeared to have limited access to the stream and signs of cattle were not as abundant. There was large woody debris at 50 percent of the sites where suckers were captured compared to 17 percent of the sites where no suckers were captured. There was a moderate amount of submerged vegetation at 71 percent of sites where suckers were captured, compared to 44 percent of the sites where no suckers were captured. All other habitat parameters appeared similar between sites where suckers were captured, and suckers were not captured.

Water quality was similar among sampling sites and parameters were within ranges known to support suckers (table 4). Dissolved oxygen, $\mathrm{pH}$, temperature and specific conductance were similar between sites where suckers were captured and those where suckers were not captured (fig. 8). The $\mathrm{HOBO}^{\circledR}$ loggers were deployed at sampling sites where suckers were not captured; however, the $\mathrm{HOBO}^{\circledR}$ loggers were placed along the creeks so that temperatures could be compared. When all six $\mathrm{HOBO}^{\circledR}$ loggers were in the water (from June 21 to July 31 ), there was a $3-4{ }^{\circ} \mathrm{C}$ average temperature increase from the farthest upstream site to the furthest downstream site in the northern (North Fork Willow Creek/Willow Creek) and southern drainages (Fletcher/Boles Creek), with similar temperatures upstream for both drainages (table 5; fig. 9). After July 31 , mean daily temperatures declined at the five sites where $\mathrm{HOBO}^{\circledR}$ loggers were still submerged (fig. 9). Sites where $\mathrm{HOBO}^{\circledR}$ loggers were placed in the southern drainage dried up from the beginning to the middle of August. As the southern drainage sites dried, daily temperatures were more variable than during the period before July 31 . After July $31, \mathrm{HOBO}^{\circledR}$ loggers in the northern drainage showed the same trends as prior to July 31 ; downstream Willow Creek temperatures remained $3-4{ }^{\circ} \mathrm{C}$ warmer and more variable than temperatures at the two upstream sites. The majority of suckers were captured in upstream sites for both drainages, so temperatures at upstream sites are likely more representative of condition at sites where suckers were encountered during this study. Both drainages measured more variable temperatures at their downstream sites. 
A

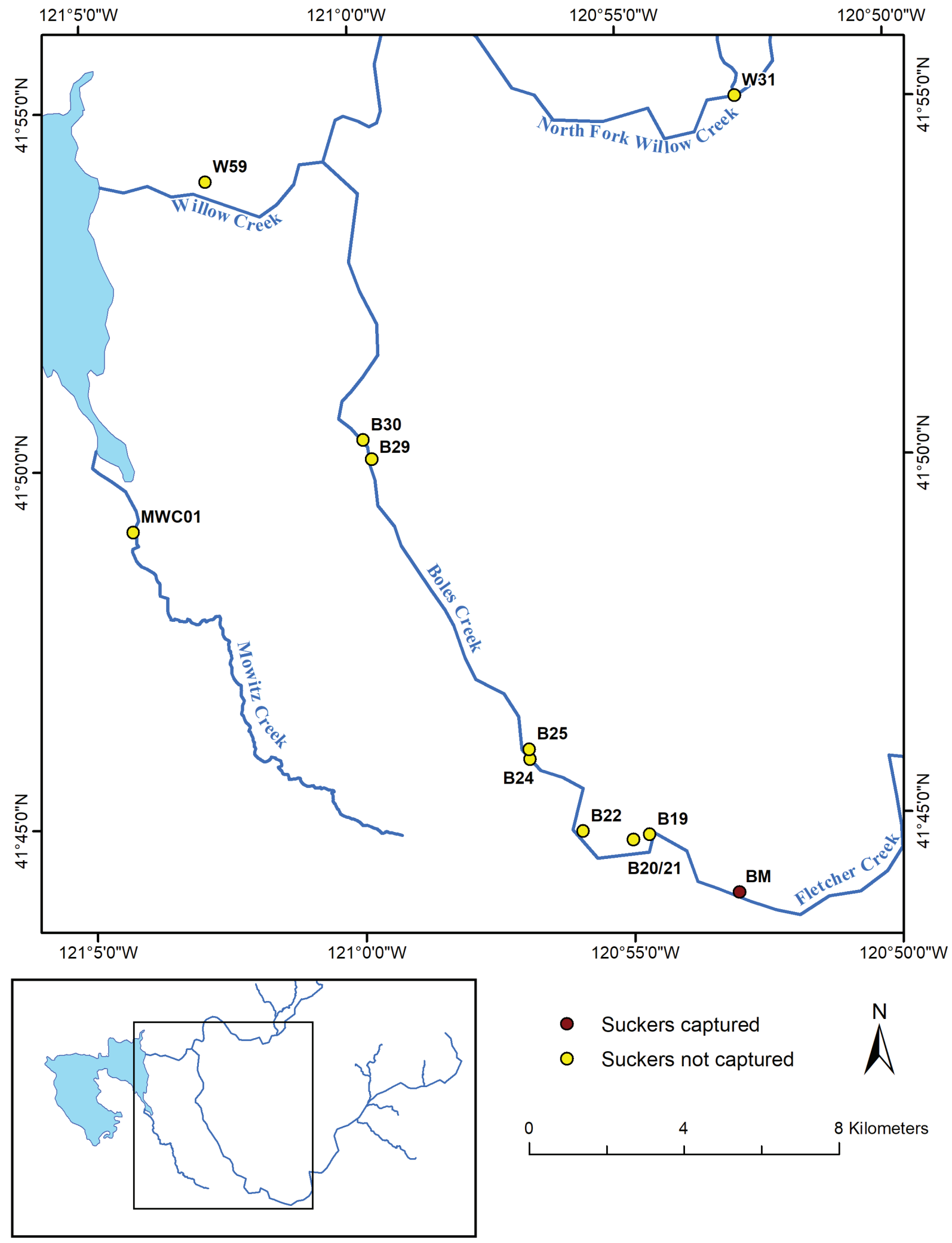

Figure 4. Expanded view of insert A from figure 2 showing sampling sites identified and labeled with site designation, Clear Lake California, 2018. 

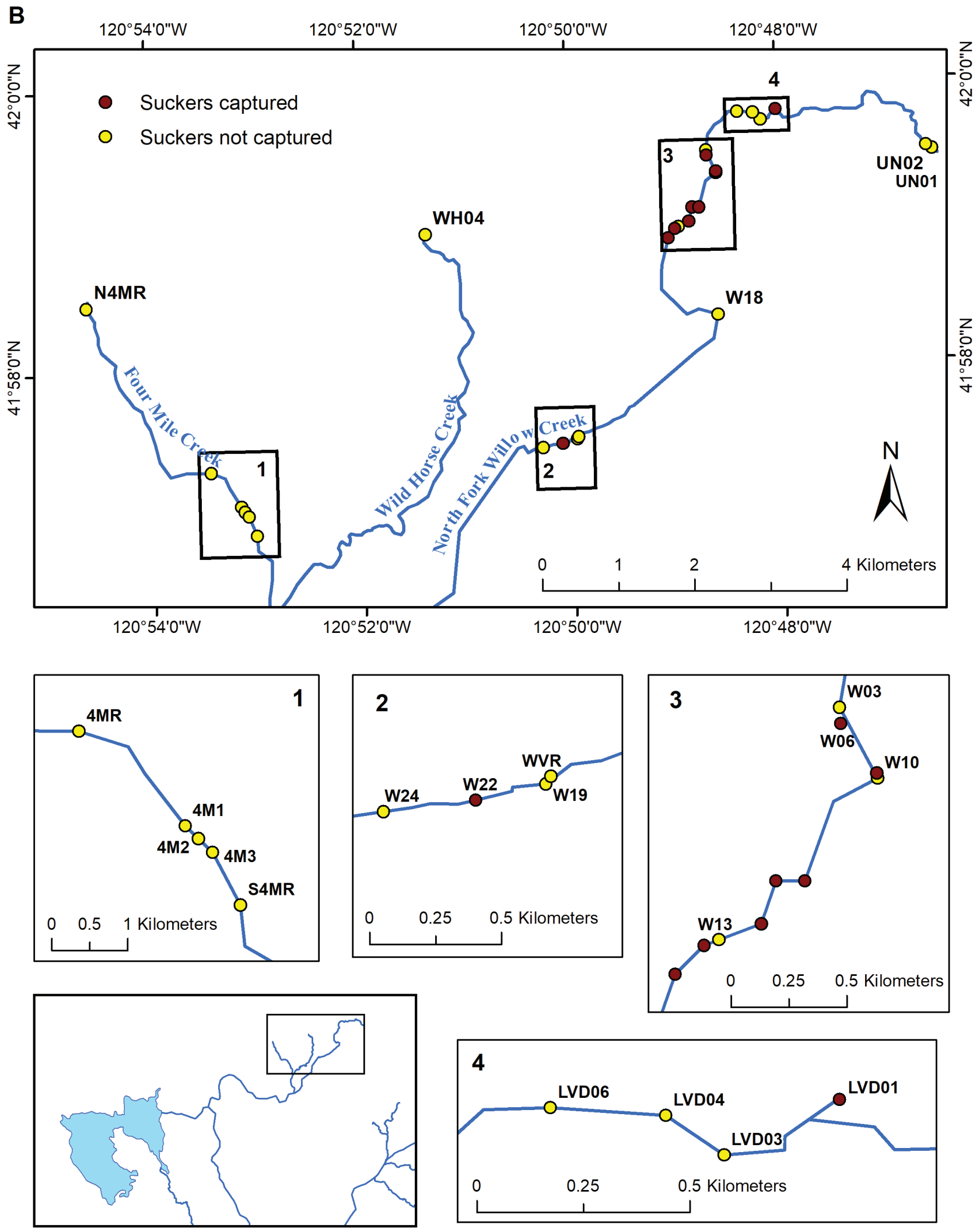

Figure 5. Expanded view of insert B from figure 2 showing sampling sites identified and labeled with site designation, Clear Lake California, 2018. Insets within this figure show further expanded views. 

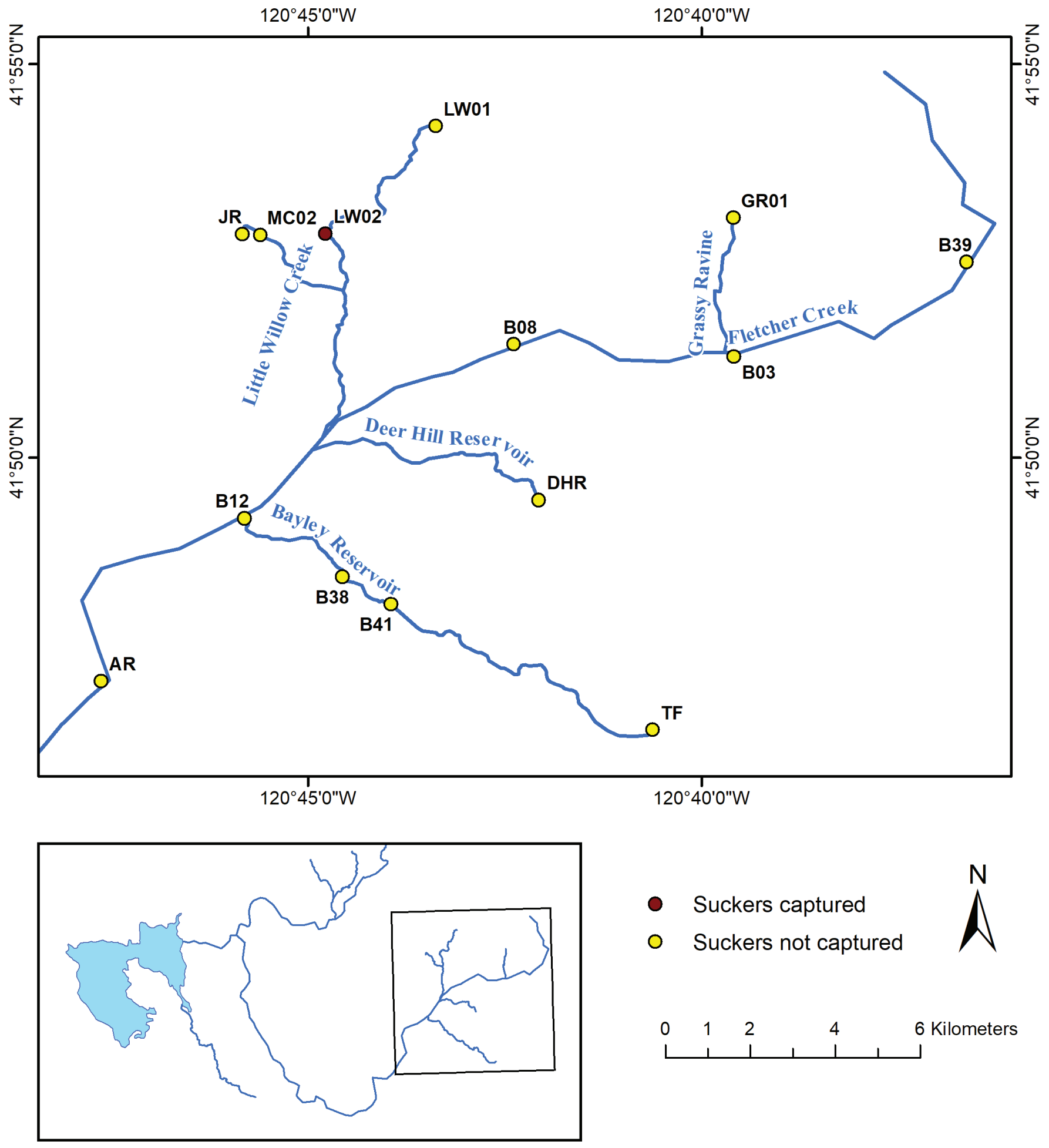

- Suckers captured

O Suckers not captured
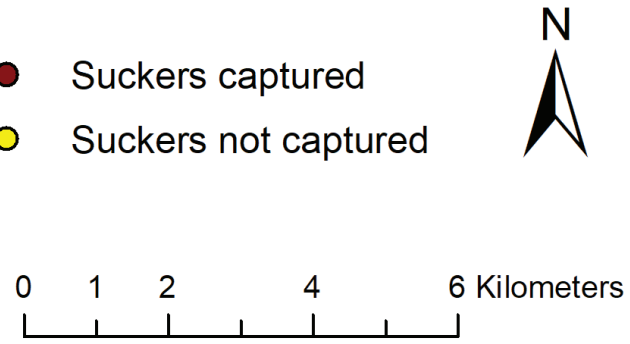

Figure 6. Expanded view of insert C from figure 2 showing sampling sites identified and labeled with site designation, Clear Lake California, 2018. 
Table 3. Number of suckers captured by site, date, sampling equipment, and effort in the Clear Lake drainage, California, 2018.

[Coordinates for sites are given in table 1. Sites were a single pool or run except where otherwise noted. The number of suckers captured are given for electrofishing first and trap netting second. No fish were captured via trammel netting. Date: mm-dd-yyyy, month-day-year. Time: hh:mm, hours: minutes. Symbol: --, not applicable]

\begin{tabular}{|c|c|c|c|c|c|}
\hline Site name & $\begin{array}{c}\text { Date } \\
\text { (mm-dd-yyyy) }\end{array}$ & $\begin{array}{l}\text { Suckers } \\
\text { captured }\end{array}$ & $\begin{array}{l}\text { Electrofishing } \\
\text { (seconds) }\end{array}$ & $\begin{array}{l}\text { Trap net } \\
\text { (hh:mm) }\end{array}$ & $\begin{array}{c}\text { Trammel net } \\
\text { (hh:mm) }\end{array}$ \\
\hline \multicolumn{6}{|c|}{ North Fork Willow Creek and tributaries } \\
\hline UN01 & $06-20-2018$ & 0 & 180 & -- & -- \\
\hline UN02 & 06-20-2018 & 0 & 244 & -- & -- \\
\hline LVD01 & 06-20-2018 & 0 & 511 & -- & -- \\
\hline${ }^{3} \mathrm{LVD} 01$ & $07-26-2018$ & 1 & -- & $23: 32$ & -- \\
\hline LVD03 & 06-20-2018 & 0 & -- & -- & $01: 15$ \\
\hline LVD04 & $06-20-2018$ & 0 & -- & -- & 01:01 \\
\hline${ }^{3} \mathrm{LVD} 04$ & $07-26-2018$ & 0 & -- & $23: 26$ & -- \\
\hline LVD06 & 06-20-2018 & 0 & 702 & -- & -- \\
\hline 1,2LVD01-LVD04 & $07-27-2018$ & 0 & 823 & -- & -- \\
\hline${ }^{1}$ LVD04-W01 & $07-26-2018$ & 0 & 1,456 & -- & -- \\
\hline W03 & 06-18-2018 & 0 & 780 & -- & -- \\
\hline W03 & 07-09-2018 & $0-0$ & 930 & $20: 30$ & -- \\
\hline W06 & 07-09-2018 & $54-4$ & 867 & $19: 15$ & -- \\
\hline W10 & 06-18-2018 & 0 & 909 & -- & -- \\
\hline${ }^{1,2} \mathrm{~W} 06-\mathrm{W} 10$ & $07-26-2018$ & 2 & 744 & -- & -- \\
\hline${ }^{1,2} \mathrm{~W} 13-\mathrm{W} 10$ & $07-25-2018$ & 7 & 3,176 & -- & -- \\
\hline W18 & 06-18-2018 & 0 & 853 & -- & -- \\
\hline W19 & 06-18-2018 & 0 & -- & -- & 02:00 \\
\hline W19 & 07-11-2018 & $0-0$ & -- & $623: 21-23: 10$ & -- \\
\hline W22 & 06-19-2018 & 1 & 550 & -- & -- \\
\hline W22 & 07-11-2018 & 0 & -- & $23: 05$ & -- \\
\hline W24 & 06-19-2018 & 0 & 331 & -- & -- \\
\hline WVR & $08-27-2018$ & 0 & -- & $23: 30$ & -- \\
\hline W31 & $06-21-2018$ & 0 & 597 & -- & -- \\
\hline W31 & $07-12-2018$ & 0 & 673 & -- & -- \\
\hline WH04 & 06-19-2018 & 0 & -- & -- & $00: 40$ \\
\hline N4MR & 08-20-2018 & 0 & -- & 23:09 & -- \\
\hline $4 \mathrm{MR}$ & $07-11-2018$ & 0 & -- & $21: 00$ & -- \\
\hline 4MR & 08-20-2018 & 0 & -- & $22: 43$ & -- \\
\hline S4MR & 08-20-2018 & 0 & -- & $22: 43$ & -- \\
\hline $4 \mathrm{M} 1$ & 06-19-2018 & 0 & 390 & -- & -- \\
\hline $4 \mathrm{M} 2$ & 06-19-2018 & 0 & 423 & -- & -- \\
\hline $4 \mathrm{M} 3$ & 06-19-2018 & 0 & 410 & -- & -- \\
\hline \multicolumn{6}{|c|}{ Willow Creek } \\
\hline W59 & $06-21-2018$ & 0 & 264 & -- & -- \\
\hline W59 & $07-10-2018$ & 0 & 723 & -- & -- \\
\hline \multicolumn{6}{|c|}{ Fletcher Creek and tributaries } \\
\hline B39 & $06-20-2018$ & 0 & 842 & -- & -- \\
\hline B03 & 06-19-2018 & 0 & 850 & -- & -- \\
\hline
\end{tabular}


Table 3. Number of suckers captured by site, date, sampling equipment, and effort in the Clear Lake drainage, California, 2018.-Continued

[Coordinates for sites are given in table 1. Sites were a single pool or run except where otherwise noted. The number of suckers captured are given for electrofishing first and trap netting second. No fish were captured via trammel netting. Date: mm-dd-yyyy, month-day-year. Time: hh:mm, hours: minutes. Symbol: --, not applicable]

\begin{tabular}{|c|c|c|c|c|c|}
\hline Site name & $\begin{array}{c}\text { Date } \\
\text { (mm-dd-yyyy) }\end{array}$ & $\begin{array}{l}\text { Suckers } \\
\text { captured }\end{array}$ & $\begin{array}{c}\text { Electrofishing } \\
\text { (seconds) }\end{array}$ & $\begin{array}{l}\text { Trap net } \\
\text { (hh:mm) }\end{array}$ & $\begin{array}{c}\text { Trammel net } \\
\text { (hh:mm) }\end{array}$ \\
\hline \multicolumn{6}{|c|}{ Fletcher Creek and tributaries-Continued } \\
\hline B08 & $06-20-2018$ & 0 & 692 & -- & -- \\
\hline B12 & 06-20-2018 & 0 & 914 & -- & -- \\
\hline AR & $08-27-2018$ & 0 & -- & $22: 43$ & -- \\
\hline GR01 & 06-20-2018 & 0 & 756 & -- & -- \\
\hline LW01 & 06-19-2018 & 0 & 850 & -- & -- \\
\hline LW02 & 06-19-2018 & 0 & 850 & -- & -- \\
\hline LW02 & 07-10-2018 & 1 & -- & $23: 10$ & -- \\
\hline MC02 & 06-19-2018 & 0 & 850 & -- & -- \\
\hline JR & $08-27-2018$ & 0 & -- & $27: 10$ & -- \\
\hline DHR & 07-09-2018 & 0 & -- & $16: 05$ & -- \\
\hline B38 & 06-20-2018 & 0 & 862 & -- & -- \\
\hline B41 & 07-09-2018 & 0 & -- & $16: 50$ & -- \\
\hline${ }^{4} \mathrm{TF}$ & 07-09-2018 & 0 & -- & -- & -- \\
\hline \multicolumn{6}{|c|}{ Boles Creek and tributaries } \\
\hline $\mathrm{BM}$ & $07-25-2018$ & $0-56$ & 592 & $21: 30$ & -- \\
\hline B19 & $07-25-2018$ & $0-0$ & 652 & $24: 07$ & -- \\
\hline B20-21 & 07-11-2018 & 0 & 591 & -- & -- \\
\hline B20-21 & $07-25-2018$ & $0-0$ & 241 & $22: 45$ & -- \\
\hline B22 & $07-25-2018$ & $0-0$ & 805 & $20: 22$ & -- \\
\hline B24 & 06-21-2018 & 0 & 995 & -- & -- \\
\hline B24 & 07-11-2018 & $0-0$ & 460 & $22: 50$ & -- \\
\hline B25 & $06-21-2018$ & 0 & 1019 & -- & -- \\
\hline B29 & 06-21-2018 & 0 & 929 & -- & -- \\
\hline B29 & $07-10-2018$ & $0-0$ & 531 & $26: 55$ & -- \\
\hline $\mathrm{B} 30$ & 07-10-2018 & $0-0$ & 850 & $27: 00$ & -- \\
\hline \multicolumn{6}{|c|}{ Mowitz Creek } \\
\hline MWC01 & 08-29-2018 & $0-0$ & 2150 & $22: 30$ & -- \\
\hline
\end{tabular}

${ }^{1}$ Sites were longer sections of stream; the beginning and end coordinates are given in table 1 by the two site designations that are separated by a dash.

${ }^{2}$ Sample location was only sampled for suckers and no bycatch was recorded.

${ }^{3}$ Sample location was sampled immediately after shocking the longer section of the stream.

${ }^{4}$ Sample location was visited but not sampled because it was dry.

${ }^{5}$ Three of the individual suckers captured by electrofishing were also captured in the trap nets.

${ }^{6}$ Two trap nets were set. 


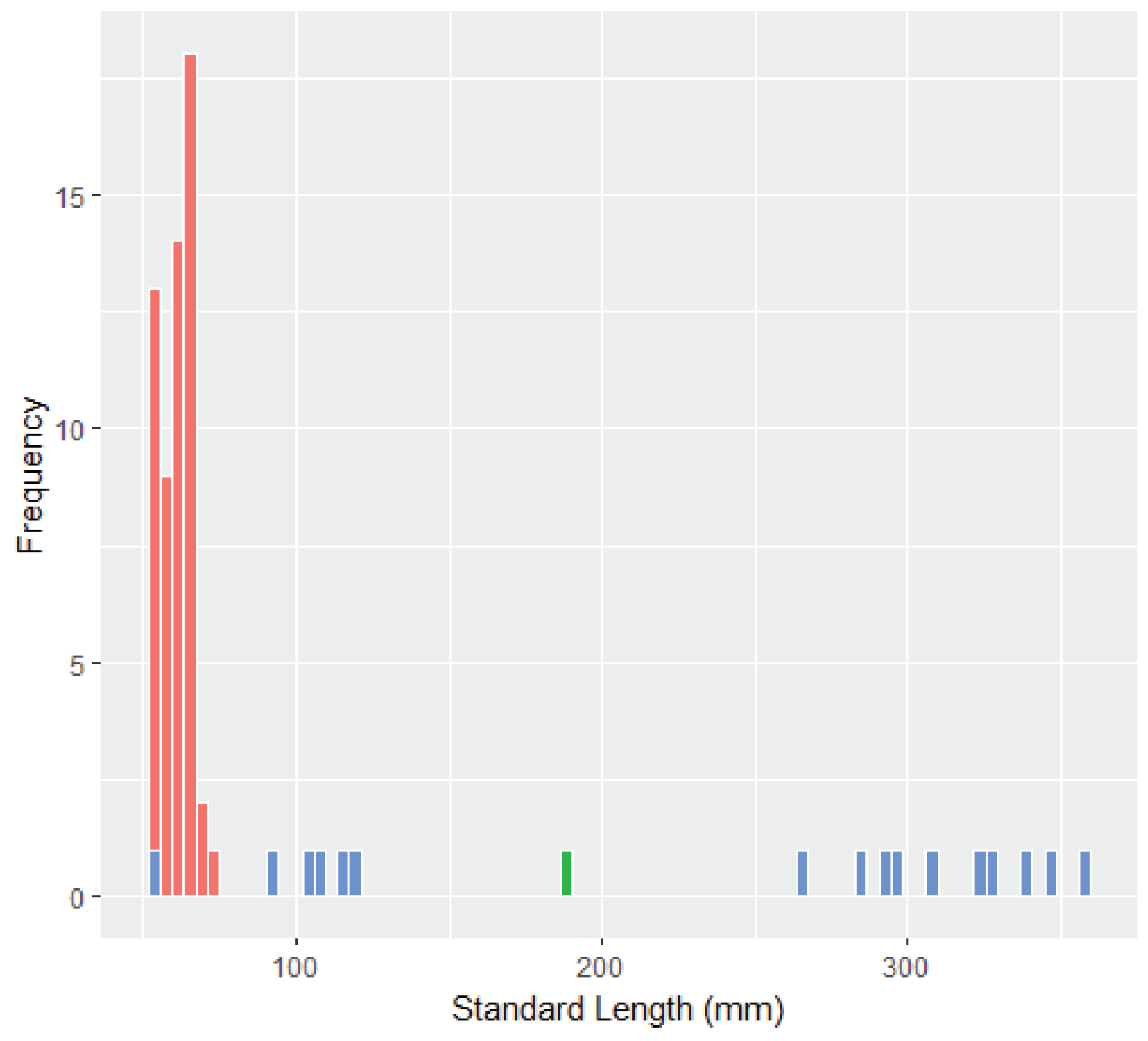

\section{Area Boles Creek Fletcher Creek N.F. Willow Creek}

Figure 7. Length frequency of suckers in millimeters $(\mathrm{mm})$ captured in the Clear Lake drainage, California, 2018. Area locations are given in table 1. 
Table 4. Water quality point sample measurements collected during surveys in the Clear Lake drainage, California, 2018.

[Coordinates for sites are given in table 1. Sites were a single pool or run except where otherwise noted. Date: mm-dd-yyyy, month-day-year, Time: hh:mm, hours: minutes. Dissolved oxygen: $\mathrm{mg} / \mathrm{L}$, milligrams per liter. Temperature: ${ }^{\circ} \mathrm{C}$, degrees Celsius. Specific conductance: $\mu \mathrm{S} / \mathrm{cm}$, microsiemens per centimeter at $\left.25^{\circ} \mathrm{C}\right]$

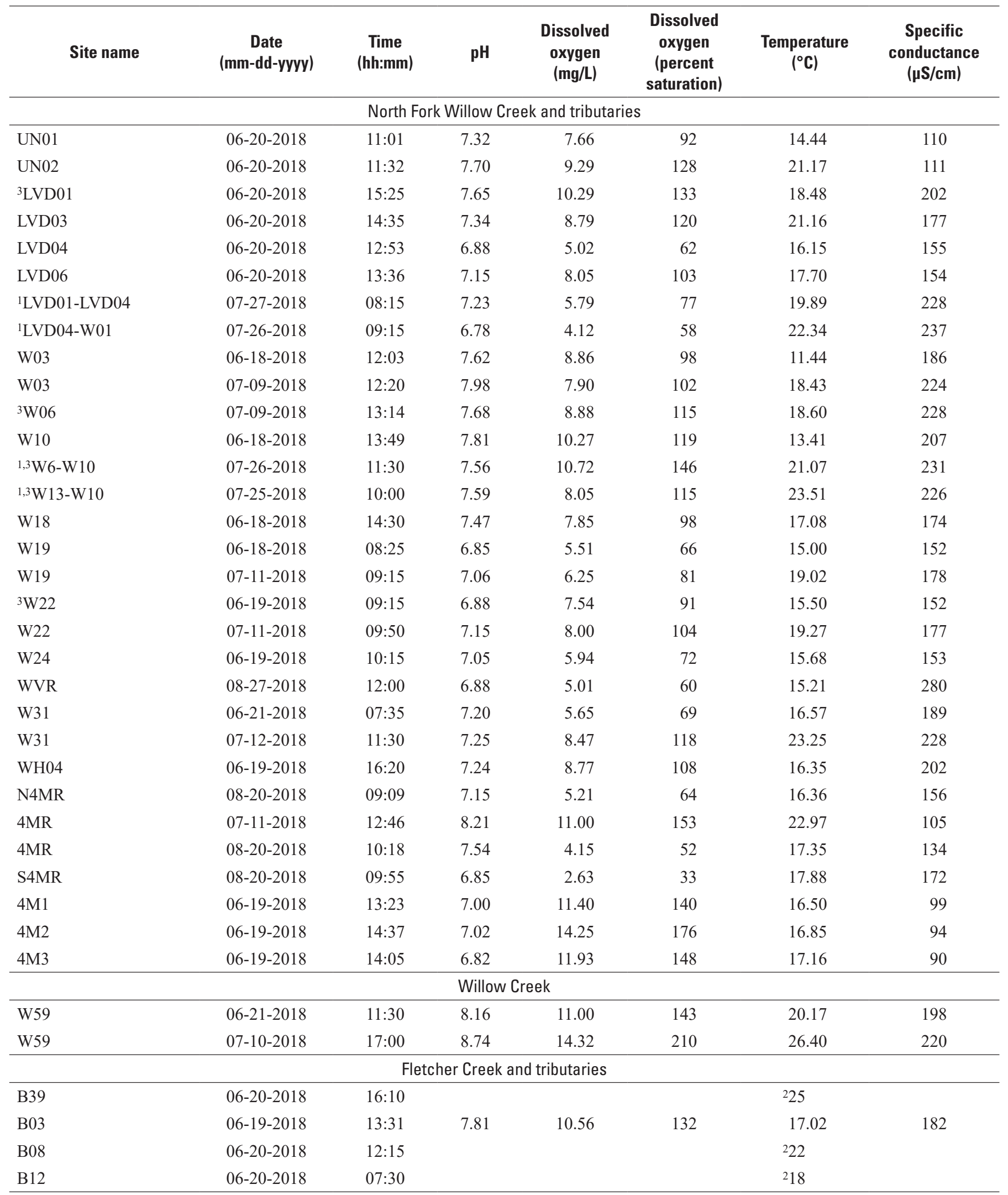


Table 4. Water quality point sample measurements collected during surveys in the Clear Lake drainage, California, 2018.-Continued

[Coordinates for sites are given in table 1. Sites were a single pool or run except where otherwise noted. Date: mm-dd-yyyy, month-day-year. Time: hh:mm, hours: minutes. Dissolved oxygen: $\mathrm{mg} / \mathrm{L}$, milligrams per liter. Temperature: ${ }^{\circ} \mathrm{C}$, degrees Celsius. Specific conductance: $\mu \mathrm{S} / \mathrm{cm}$, microsiemens per centimeter at $\left.25^{\circ} \mathrm{C}\right]$

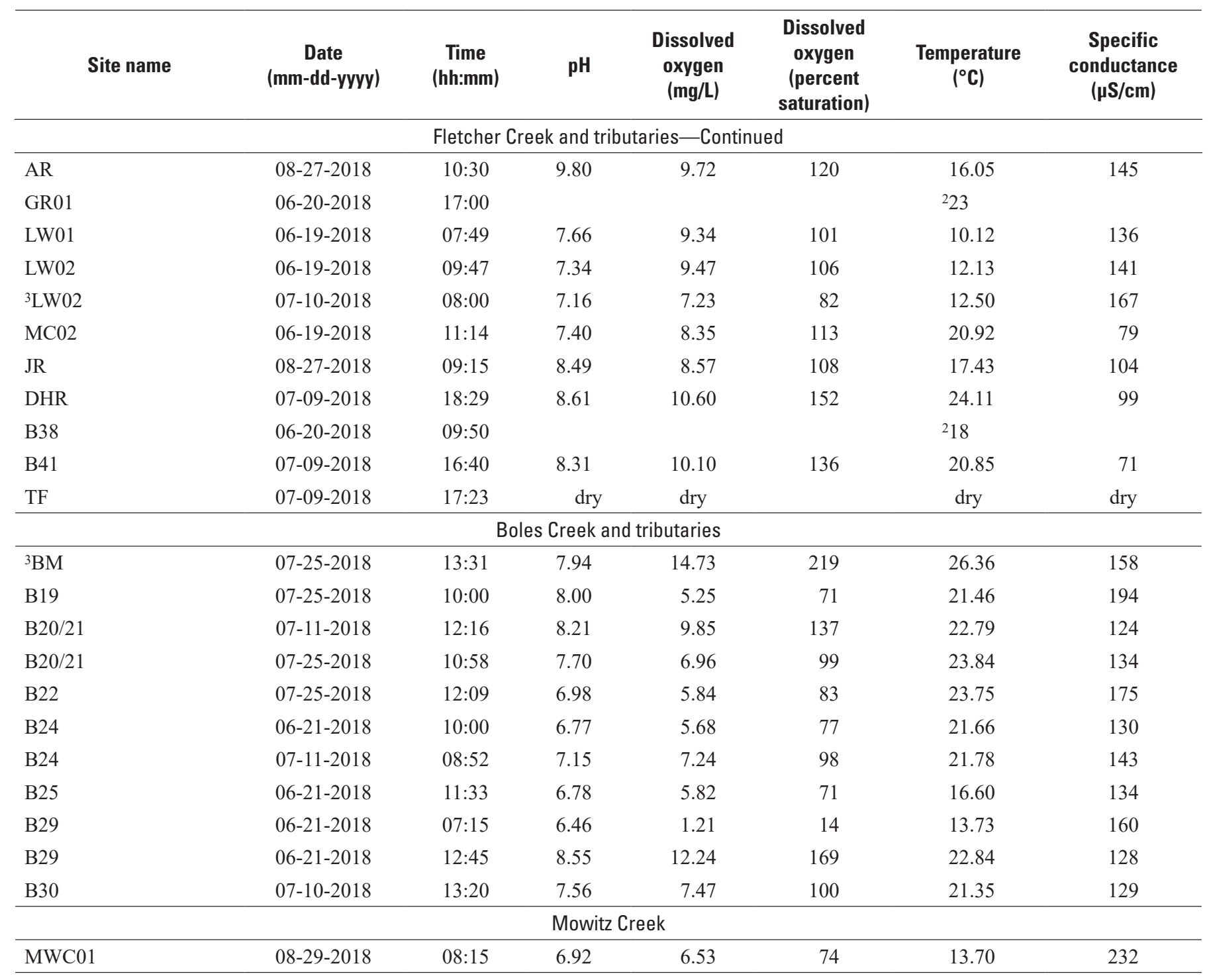

${ }^{1}$ These sites were longer sections of stream; the beginning and end coordinates are given in table 1 by site designation.

${ }^{2}$ YSI Sonde was not working and temperature was taken by a thermometer.

${ }^{3}$ Sites where suckers were captured. 


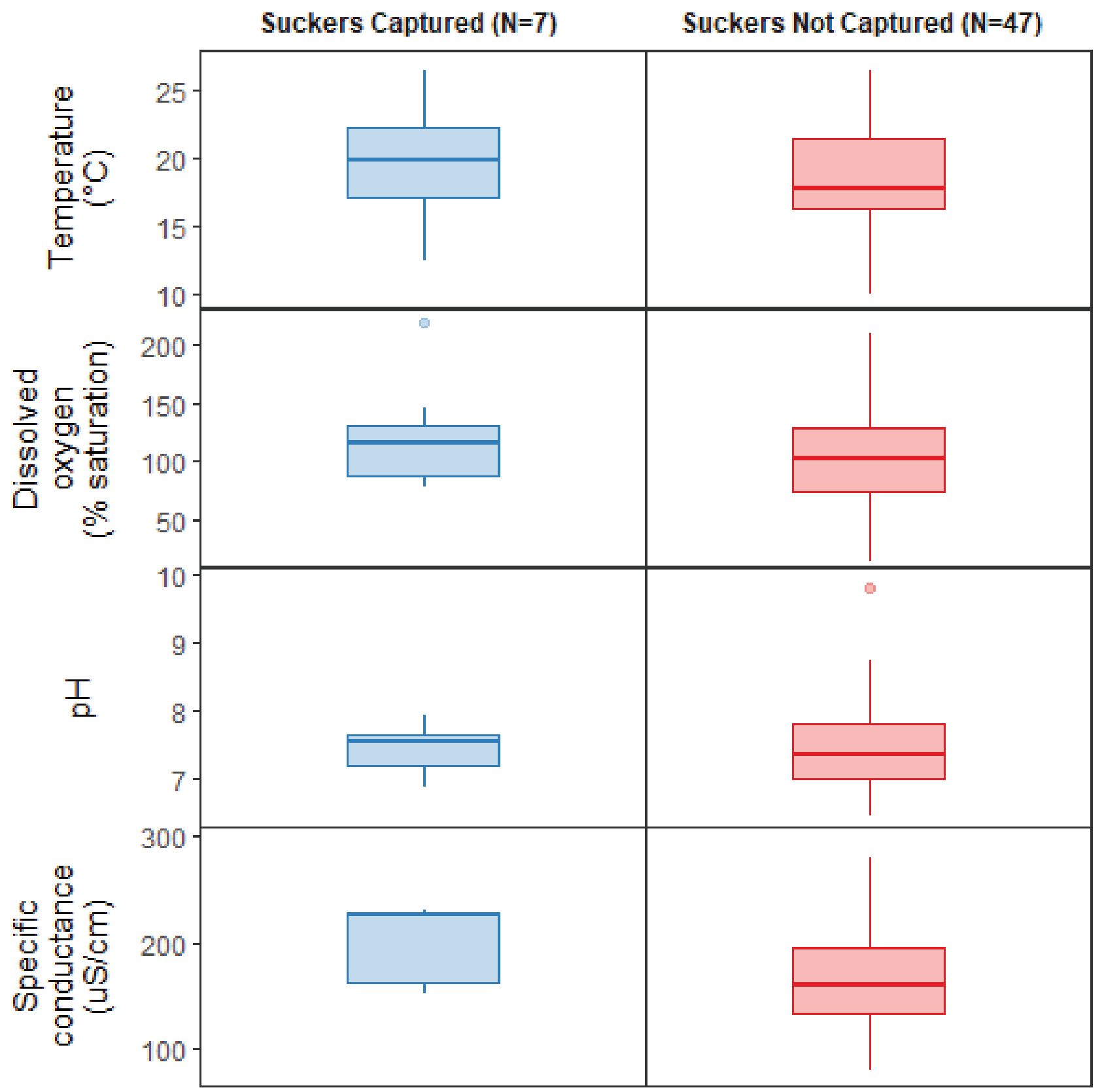

Figure 8. Comparisons of water quality between sites where suckers were captured and where suckers were not captured in the Clear Lake drainage, California, 2018. Boxes show the 25th and 75th percentiles, bold lines in the boxes are the median, whiskers indicate the 5 th and 95 th percentiles, and the dots indicate outliers. [N, number of suckers; ${ }^{\circ} \mathrm{C}$, degrees $\mathrm{Celsius;} \%$, percent; $\mu \mathrm{S} / \mathrm{cm}$, microsiemens per centimeter.] 
Table 5. General statistics for temperature readings in degrees Celsius $\left({ }^{\circ} \mathrm{C}\right)$ from $\mathrm{HOBO}{ }^{\circledR}$ loggers at six sites, two drainages, in California from June 21, 2018 through July 31, 2018.

[Sites are ordered from upstream to downstream for each drainage. SD: Standard deviation. Min: Minimum. Max: Maximum]

\begin{tabular}{llllccc}
\hline Drainage & Creek & Site & Mean & SD & Min & Max \\
\hline Northern & Willow & W03 & 19.4 & 2.3 & 13.2 & 25.0 \\
Northern & Willow & W31 & 22.2 & 2.2 & 15.7 & 26.6 \\
Northern & Willow & W59 & 23.2 & 2.7 & 17.4 & 30.3 \\
Southern & Fletcher & B12 & 20.0 & 1.6 & 15.2 & 25.0 \\
Southern & Boles & B24 & 23.4 & 1.6 & 18.9 & 27.1 \\
Southern & Boles & B29 & 23.0 & 2.6 & 17.3 & 30.3 \\
\hline
\end{tabular}

Nonnative green sunfish (Lepomis cyanellus) were abundant throughout the Clear Lake drainage and the relative abundance of other fishes varied among streams (table 6). Green sunfish was the only species to be found in greater than 50 percent of the sites in each of the main creeks and their tributaries. Nonnative bullheads (Ameiurus sp.) and green sunfish were the most abundant fishes overall, with the majority of bullheads being captured in North Fork Willow Creek. Bullheads, followed by green sunfish, were the most abundant species in North Fork Willow Creek, and nonnative fathead minnows (Pimephales promelas), followed by green sunfish, were the most abundant species in Willow Creek. In Fletcher Creek green sunfish were the most numerous species captured, followed by native speckled dace (Rhinichthys osculus), in Boles Creek native tui chub were the most numerous species followed by green sunfish, and in Mowitz Creek green sunfish were the most numerous species followed by nonnative bluegill (Lepomis macrochirus). The combination

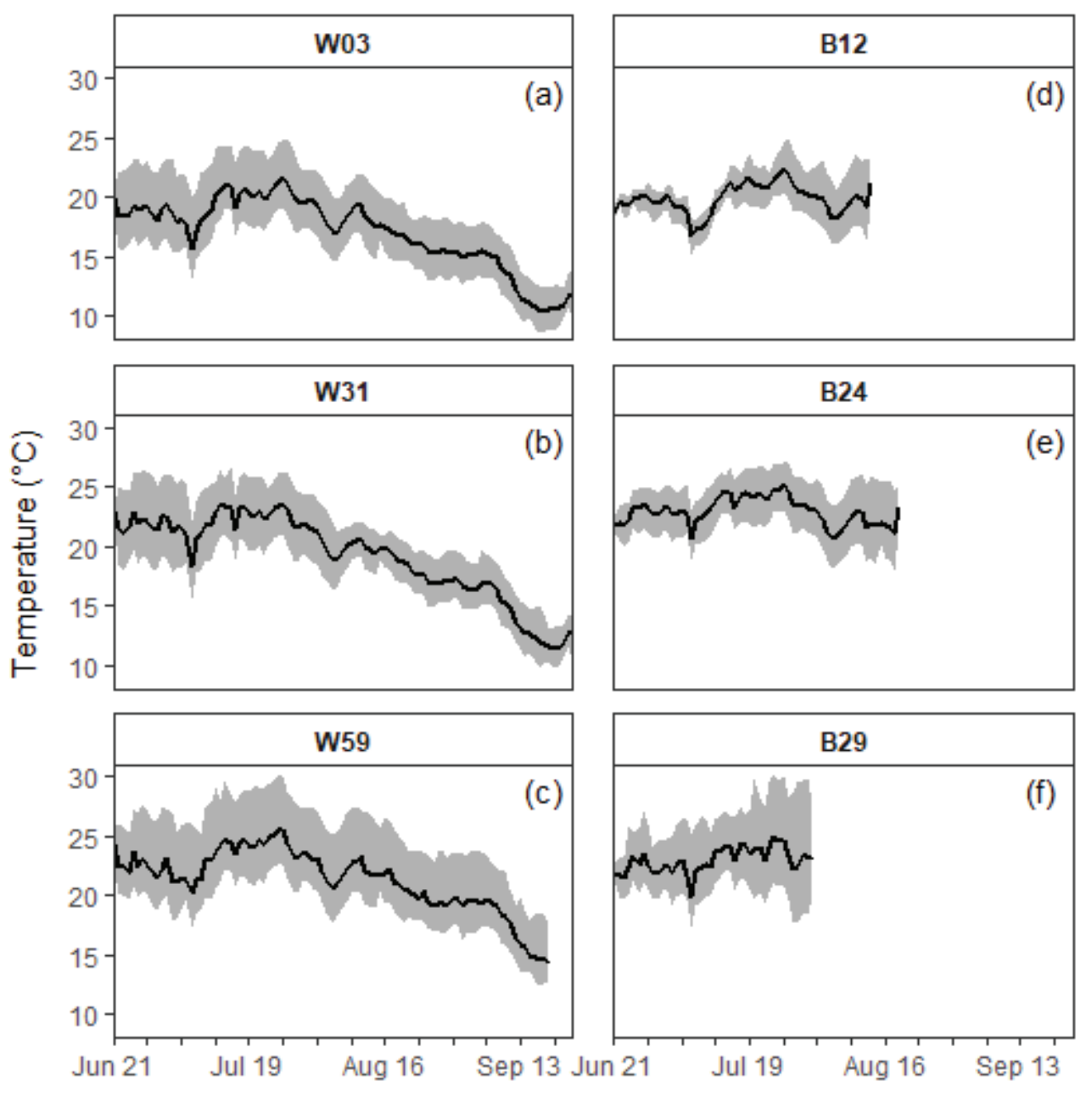

Figure 9. Daily mean temperatures (lines) with the daily range (shaded areas) of water temperatures at the six sites where $\mathrm{HOBO}{ }^{\circledR}$ loggers were placed in the Clear Lake drainage, California, 2018. Sites were (a) W03, (b) W31, and (c) W59 from the Northern drainage, and (d) B12, (e) B24, and (f) B29 from the Southern drainage. [ ${ }^{\circ} \mathrm{C}$, degrees Celsius.] 
Table 6. Numbers of fish species captured in each of the major creeks and their tributaries in the Clear Lake drainage, California, 2018.

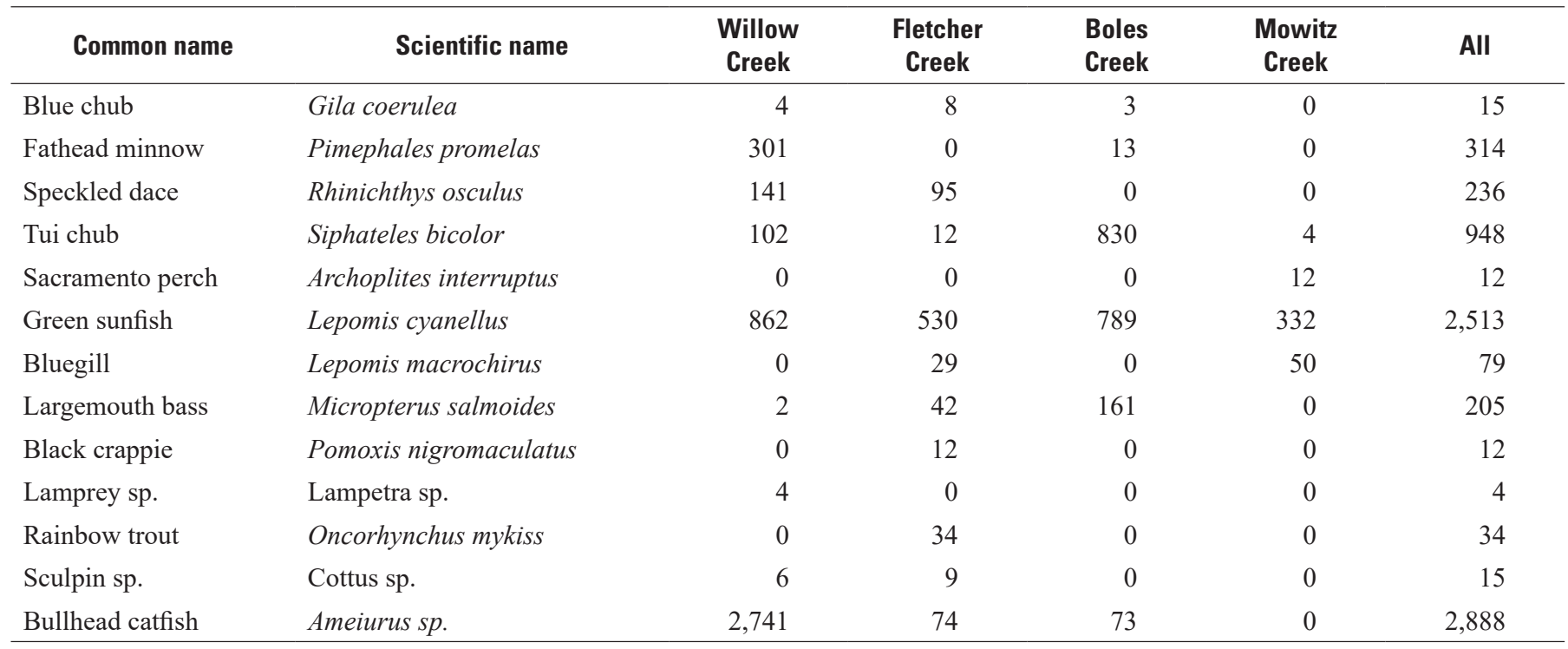

of the two most abundant species at each of the major creeks comprised 74-96 percent of the catch within a creek, with each of these individual species comprising a minimum of 10 percent of the total catch at a creek. Each of the remaining species comprised less than 10 percent of the catch at a creek. Species that were captured with suckers in North Fork Willow Creek and its tributaries were green sunfish, fathead minnows, speckled dace, and blue chub (Gila coerulea). Species that were captured with suckers in Little Willow Creek, a tributary of Fletcher Creek, were rainbow trout (Oncorhynchus mykiss) and tui chub. Species that were captured with suckers in the Boles Meadow area of Boles Creek were green sunfish, largemouth bass (Micropterus salmoides), bullheads, tui chub, and blue chub. The species captured with suckers in Boles Creek and North Fork Willow Creek were the most abundant species captured in those areas; however, in Fletcher Creek the two species captured with suckers, rainbow trout and tui chub, only comprised a small portion of the fish captured in that area.

Twelve of the 15 nontarget species captured during this study had at least one individual measured (table 7). The majority of these fish were less than $165 \mathrm{~mm}$ SL. Only three species (bullheads, largemouth bass, and rainbow trout) had individuals greater than $200 \mathrm{~mm}$ SL. Length frequencies of the two most abundant native and three most abundant nonnative species are shown in figure 10. The two most abundant nonnative species (bullhead and green sunfish) had larger size ranges than the other nonnative species (fathead minnow) and the two native species (speckled dace and tui chub). Bullheads were evenly distributed over the entire range of sizes, potentially indicating a variety of ages. Green sunfish lengths spanned $141 \mathrm{~mm}$ and were dispersed in a pattern similar to a bell-shaped curve, with a couple of dips that might indicate age breaks. Fathead minnows had the tightest length range of $25 \mathrm{~mm}$, with a mean of $52 \mathrm{~mm} \mathrm{SL}$ and a single mode. The tui chub had a large length range $(90 \mathrm{~mm})$ and appeared to have three modes indicating three potential age groups. Speckled dace had a tighter length range $(43 \mathrm{~mm})$ than all species except for fathead minnows and showed a single mode.

Table 7. Number of nontarget fish measured in the Clear Lake tributaries and the mean, minimum, and maximum standard length for each species, California, 2018.

[ $N$, number of observations; SL, standard length; mm, millimeters $]$

\begin{tabular}{lrccc}
\hline \multicolumn{1}{c}{ Common name } & N & $\begin{array}{c}\text { Mean } \\
\text { SL (mm) }\end{array}$ & $\begin{array}{c}\text { Minimum } \\
\text { SL (mm) }\end{array}$ & $\begin{array}{c}\text { Maximum } \\
\text { SL (mm) }\end{array}$ \\
\hline Blue chub & 12 & 53 & 28 & 90 \\
Fathead minnow & 46 & 52 & 38 & 63 \\
Speckled dace & 39 & 66 & 48 & 91 \\
Tui chub & 47 & 78 & 37 & 127 \\
Sacramento perch & 8 & 105 & 71 & 132 \\
Green sunfish & 188 & 83 & 22 & 163 \\
Bluegill & 15 & 78 & 62 & 92 \\
Largemouth bass & 17 & 80 & 34 & 232 \\
Rainbow trout & 11 & 150 & 31 & 225 \\
Sculpin sp. & 11 & 58 & 27 & 83 \\
Bullhead catfish & 72 & 124 & 33 & 229 \\
\hline
\end{tabular}




\section{Bullhead}

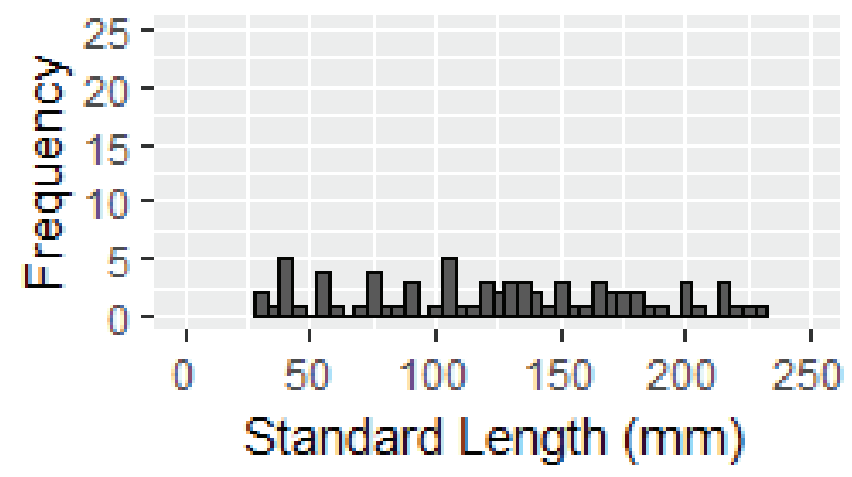

\section{Fathead minnow}

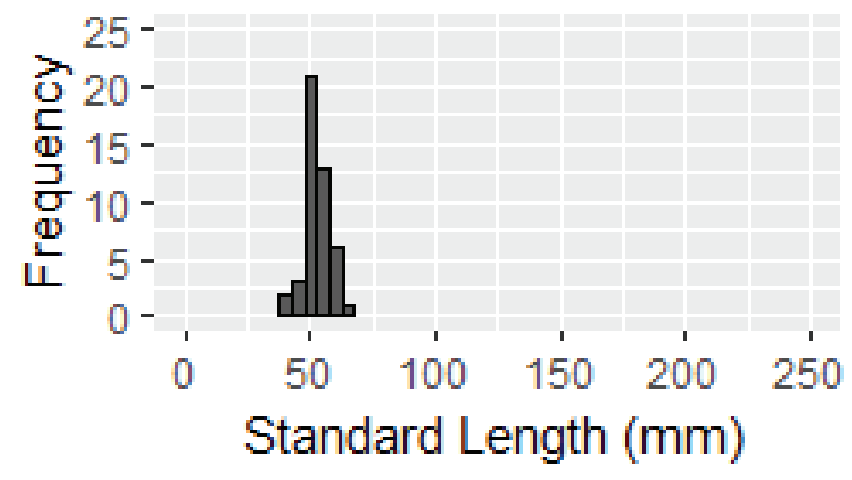

\section{Green sunfish}

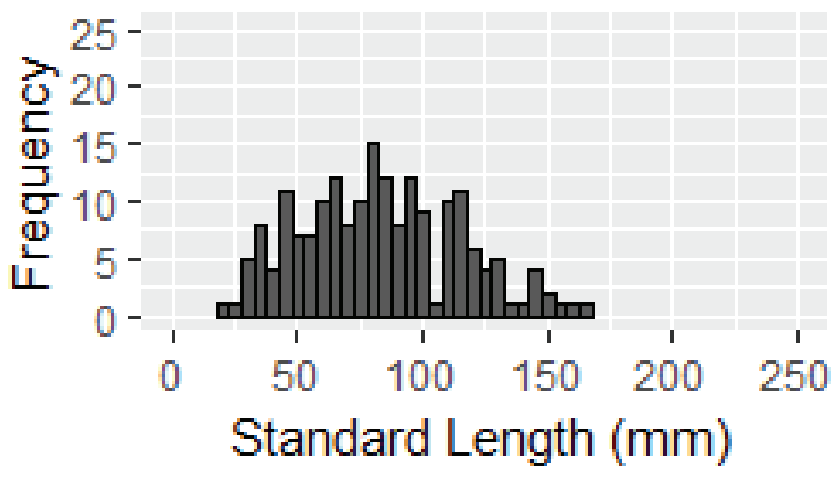

Speckled dace

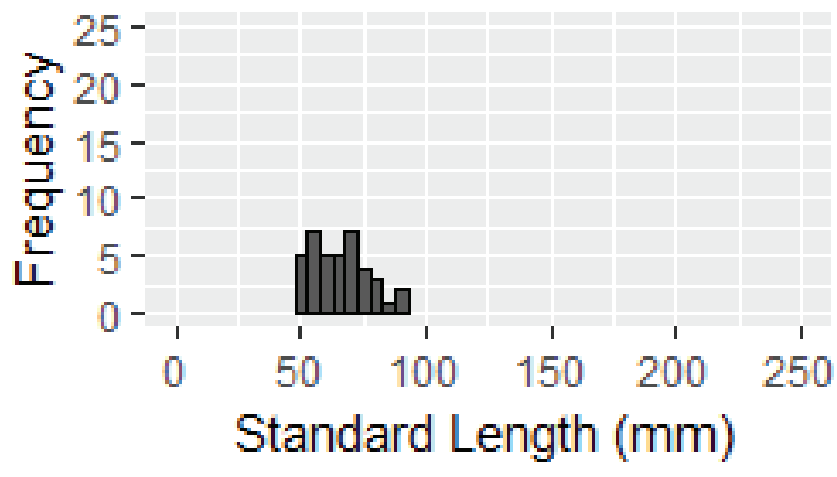

\section{Tui chub}

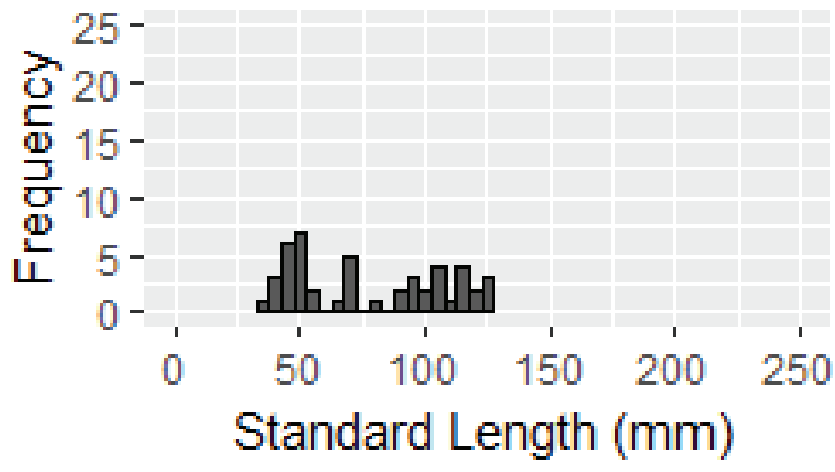

Figure 10. Length frequencies of the most abundant nontarget species captured in the Clear Lake drainage, California, 2018. [mm, millimeters.] 


\section{Gerber Reservoir Drainage}

Suckers were mostly found in pools and runs within the Gerber Reservoir drainage with fine substrate, little submerged vegetation, and in depths ranging from 0.5 to $1.0 \mathrm{~m}$. Riparian vegetation was generally meadow habitat in Barnes Valley and Long Branch Creeks, and alders in Lapham Creek. Water quality was similar among sampling sites and fell within ranges known to be acceptable for suckers (table 8). Livestock were not present at the time of sampling at any of the sites, however; there were signs of heavy grazing at all sites except for Lapham Creek. A total of 44 suckers were captured across all six locations sampled in the tributaries to Gerber Reservoir (tables 9-10; fig. 3). We captured the greatest number of suckers at the highest catch per unit effort (CPUE) in Barnes Valley Creek, where water temperatures were the warmest of the three streams sampled. Suckers in Barnes Valley Creek were mostly captured within one large pool. We captured the fewest suckers at the lowest catch per unit effort in Lapham Creek, where specific conductance was the lowest of the three creeks sampled. Lapham Creek was the only sampling site that had flowing water instead of still water, and the pools were too deep to electrofish. Consequently, the two suckers captured in Lapham Creek were captured in runs. The two sampling sites on Long Branch Creek had CPUEs about half that of Barnes Valley Creek. Suckers captured in Long Branch Creek were found in shallow pools.

Suckers captured in the tributaries to Gerber Reservoir ranged from 52 to $259 \mathrm{~mm}$ SL and were age- 0 to age- 6 . The majority of suckers captured ( 89 percent) in the Gerber Reservoir tributaries were less than $200 \mathrm{~mm}$ SL and were not identified to species using morphology (fig. 11). All fish that were large enough to identify using morphological characteristics $(n=5)$ were identified as Klamath largescale suckers. Barnes Valley Creek was the only site where enough suckers were captured to indicate that there were two distinct size classes. At Barnes Valley Creek, suckers less than or equal to $161 \mathrm{~mm}$ SL were age- 0 or age-1, while suckers greater than or equal to $174 \mathrm{~mm}$ were age- 3 to age- 6 . Most suckers in Gerber Reservoir tributaries measuring less than $125 \mathrm{~mm} \mathrm{SL}$ and were age- 0 or age-1; whereas, those greater than $125 \mathrm{~mm}$ SL were age-2 to age- 6 . There was one exception; a sucker from Barnes Valley Creek that was $161 \mathrm{~mm}$ SL and was age-1. All suckers appeared healthy, with no external afflictions observed. 


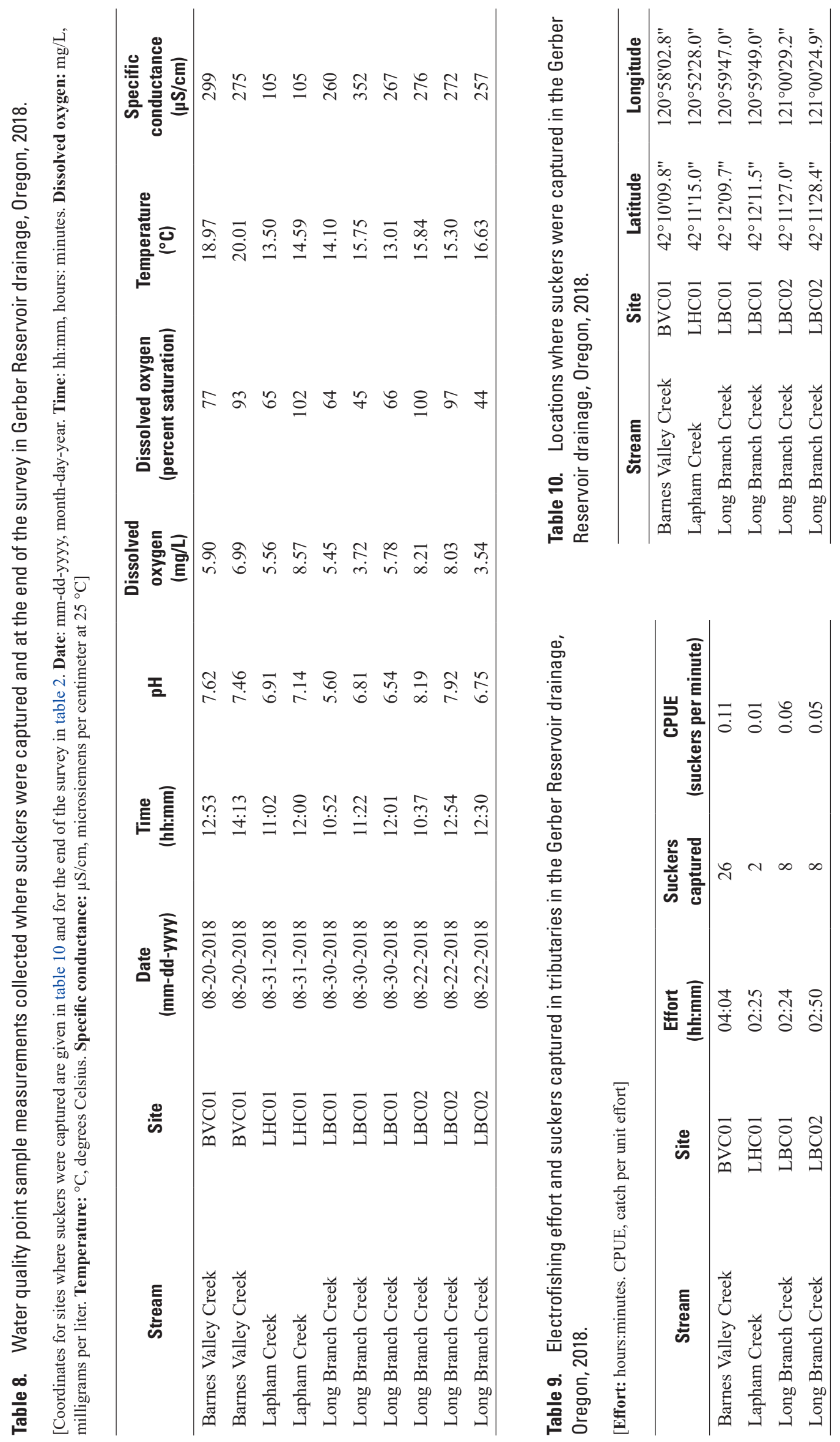




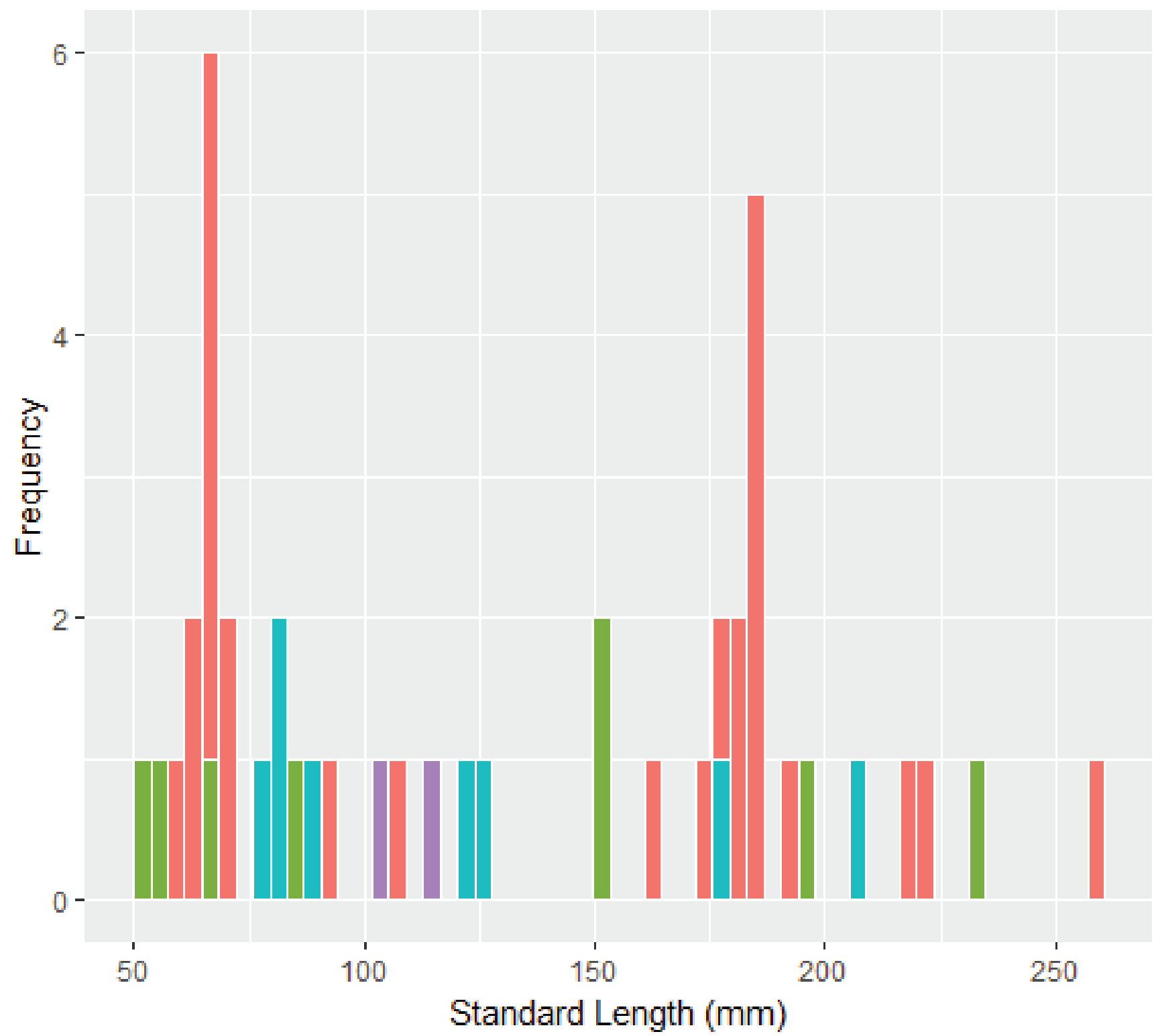

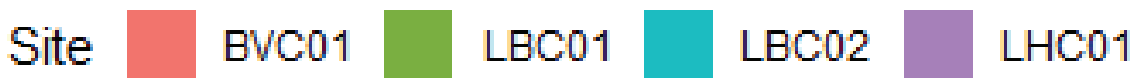

Figure 11. Length frequency of suckers captured at four sample sites in the Gerber Reservoir drainage, Oregon, August 2018. Site locations are listed in tables 2 and 10. 


\section{Discussion}

We did not capture Lost River suckers during our study; however, previous studies (Sonnevil, 1972; Koch and Contreras, 1973; Koch and others, 1975; Buettner and Scoppettone, 1991) identified both Lost River suckers and shortnose suckers in the Clear Lake watershed, with shortnose suckers more abundant. Koch and Contreras (1973) collected a large number of spawning Lost River suckers in Willow Creek within $4 \mathrm{~km}$ of Clear Lake. Sonnevil (1972) found six Lost River suckers in Willow Creek within 2.5 miles of Clear Lake, Koch and others (1975) found two Lost River suckers in a pool in North Fork Willow Creek, whereas Buettner and Scoppettone (1991) found 11 Lost River suckers: 6 in Boles Creek, 4 in Avanzino Reservoir, and 1 in North Fork Willow Creek. All Lost River suckers from the previous studies were larger juveniles or adults (average of: $249 \mathrm{~mm}$ SL in Sonnevil, 1972; 423 mm SL in Koch and others, 1975; 495 mm SL in Buettner and Scoppettone, 1991). At the time of the previous studies, genetic markers had not been identified to separate out any of the sucker species; consequently, these studies primarily relied on morphological characteristics, sacrificing a subset of their catch for meristics and morphometrics. Buettner and Scoppettone (1991) found that Lost River suckers from the Clear Lake watershed were meristically and morphometrically similar to those from Upper Klamath Lake and were therefore confident in their identification.

Shortnose suckers in Clear Lake do not resemble the shortnose suckers in Upper Klamath Lake, and since these suckers were initially described in Clear Lake, there has been a debate as to the proper classification of the species as shortnose, Klamath largescale, or hybrids (Koch and Contreras, 1973; Andreasen, 1975; Miller and Smith, 1981; Buettner and Scoppettone, 1991). Buettner and Scoppettone (1991) found the shortnose suckers from the Clear Lake watershed differing from those in Upper Klamath Lake and Copco Reservoir both meristically and morphometrically. Furthermore, they separated Clear Lake watershed shortnose suckers into three groups based on capture location and potential breeding isolation: the shortnose suckers from upper North Fork Willow Creek were more like Klamath largescale suckers, while the shortnose suckers from Clear Lake and the watershed above Clear Lake, excluding upper North Fork Willow Creek, were more like the shortnose suckers in Upper Klamath Lake. Although the previous studies acknowledged the uncertainty of the identification of shortnose suckers in the Clear Lake watershed, neither study assigned any of their catches as Klamath largescale suckers. Using morphological identification we speculated that the suckers collected in the upper part of North Fork Willow Creek were mostly Klamath largescale suckers with a couple of shortnose suckers. We assume that the suckers we collected in the upper part of North Fork Willow Creek were the same species that Buettner and Scoppettone (1991) collected and could be Klamath largescale suckers, shortnose suckers, or a hybrid between the two. A recent genetic study on 139 morphologically identified shortnose suckers from the Lost River Basin, indicated that 100 percent of these sample were indistinguishable from Klamath largescale suckers collected from both Upper Klamath Lake $(n=67)$ and the Lost River Basin $(n=16)$, whereas all 113 shortnose suckers from Upper Klamath Lake were shown to be genetically different from all 83 Klamath largescale suckers (Smith and others, 2020). Therefore, it is possible that all the suckers we collected during this study, including the two that we called shortnose suckers, were Klamath largescale suckers.

During our study and the previous studies, the majority of suckers were captured in lentic waters with mud and fine substrate. Koch and others (1975) found 19 of their 21 suckers in reservoirs, with the two additional shortnose suckers collected in Boles Meadow. However, Koch and others (1975) determined that Boles Creek was not suitable habitat due to the high silt load. Buettner and Scoppettone (1991) found larger shortnose suckers in Avanzino Reservoir $(n=14)$ and upper North Fork Willow Creek $(n=24)$ and young of year suckers presumed to be shortnose suckers in reservoirs and pools of North Fork Willow and Boles creeks. During this study no suckers were captured in these small reservoirs within the Clear Lake watershed; however, only minimal effort was applied to sampling these areas. Instead suckers were mostly captured in stream pools within wet meadows, with a few suckers captured within stream runs. North Fork Willow Creek is a perennial creek and it has the greatest flow compared to Boles, Mowitz, and Fletcher creeks. Within North Fork Willow Creek, the majority of suckers were found at site W13-W10, which was mostly run habitat within a canyon with very little cattle grazing noted, and the riparian area was mainly composed of sedges and rushes. Given that, Boles, Fletcher, and Mowitz Creeks are intermittent or very shallow during the summer months, suckers may have occupied the pools and meadows because they were the only habitat available to them. We collected our larger Klamath largescale/ shortnose suckers in upper North Fork Willow Creek and Little Willow Creek, and our young of year Klamath largescale/shortnose suckers in Boles Creek, which overlapped some of the areas where two of the other studies found shortnose suckers of similar sizes and ages (Koch and others, 1975; Buettner and Scoppettone, 1991). During this study, younger fish were found in lentic waters and larger fish were found in lotic waters; this is a characteristic of other Catostomidae species similar to Klamath largescale sucker (Moyle, 2002; Hayes and Rasmussen, 2017).

The majority of juvenile suckers we captured in the Clear Lake drainage were found in ponded water within Boles Meadow, behind a water retention structure. The standing water was evaporating and drying rapidly leading to increased water temperatures. Water temperatures were warm and we suspect that this site dried out after our visit, making the survival of the fish found in Boles Meadow unlikely. Buettner and Scoppettone (1991) suspected that the adult Lost River suckers they captured in Boles Creek and Avanzino Reservoir were stranded spawning individuals. In the summers of 2016 and 2017, this suspicion was confirmed when telemetered adult suckers in Boles Meadow died after the water diversion structure was closed and the fish were trapped (Banet and 
others, 2021). Therefore, while deep pools may be providing refuge, wet meadows that warm up and dry out may be hazardous to suckers.

During this study suckers were primarily captured in depths of 0.5 to $3.0 \mathrm{~m}$, with most captured in waters of $1.0 \mathrm{~m}$ or less. Buettner and Scoppettone (1991) captured suckers in depths of 1-2 $\mathrm{m}$ with visibility usually less than a meter. Buettner and Scoppettone (1991) found suckers in areas with substantial standing crops of rooted aquatic plants, while we did not find this in our study. During this study suckers were not captured in 46 percent of the sites with greater than 20 percent submerged vegetation. Grazing activity was noted in the previous studies as a major problem leading to streambank and soil instability, possibly affecting habitat quality. We also noted cattle grazing at most sites; however, at site W13-W10 signs of cattle were not as abundant because cattle appeared to have limited access to the stream and suckers were relatively abundant.

Although this study, Koch and others (1975), and Buettner and Scoppettone (1991) all measured point samples of water quality, there were no definitive water quality differences between locations where suckers were captured or not captured. In this study, specific conductance was higher at sites where suckers were captured than where they were not captured. Higher specific conductance was likely an indication that the habitats where suckers were found were still rather than moving waters. Buettner and Scoppettone (1991) found water temperatures slightly higher $\left(14\right.$ to $\left.28^{\circ} \mathrm{C}\right)$ and dissolved oxygen slightly lower ( 0.7 to 13.6 milligrams per liter $[\mathrm{mg} / \mathrm{L}])$ than what was found during this study $\left(10\right.$ to $26^{\circ} \mathrm{C}$ and 1.21 to $14.73 \mathrm{mg} / \mathrm{L})$. Suckers were not captured in locations with dissolved oxygen levels below $6 \mathrm{mg} / \mathrm{L}$ (77 percent saturation) during this study; however, they were found at temperatures up to $26^{\circ} \mathrm{C}$. Consequently, sites where suckers were found, appeared to be within tolerances of suckers (Saiki and others, 1999). However, the point reading of temperature at Boles Meadow $\left(26^{\circ} \mathrm{C}\right)$ (taken at $13: 31$ on July 25,2018$)$ approached the $\mathrm{LC}_{50}$ (lethal concentration with 50 percent mortality) of Lost River suckers $\left(31^{\circ} \mathrm{C}\right)$ and due to the shallow depth, likely reached the upper limit of Lost River sucker temperature tolerance.

Consistent with Buettner and Scoppettone (1991), this study found the majority of suckers in the Clear Lake tributaries were juveniles. During this study, multiple cohorts of suckers were found in the Clear Lake tributaries with suckers ranging from age-0 to age-9. Buettner and Scoppettone (1991) aged a subset of the suckers captured by counting the rings on the opercular bones of preserved specimens. Lost River suckers captured in the Clear Lake tributaries in 1989-90 were age- 4 to age- 6 , while the shortnose suckers were age- 1 to age-11 (Buettner and Scoppettone, 1991). Both structures have false annuli and are hard to read at older ages due to crowding of annuli. Therefore, older fish in both studies are less likely to have been assigned the proper age.
The fish assemblage changed from primarily natives in the previous studies to primarily nonnatives in the present study. In 1973 and 1975 the fish community was primarily composed of tui chub and speckled dace with a few sculpin (Sculpin sp.), lamprey, and bullheads captured in North Fork Willow Creek/Willow Creek and a few largemouth bass and green sunfish collected in Boles Creek (Sonnevil 1972; Koch and others 1975). The species assemblage was already changing by the time Buettner and Scoppettone (1991) sampled in 1989-1990. While the primary species they captured was tui chub, the secondary species was no longer speckled dace, it was green sunfish. Buettner and Scoppettone (1991) captured three times as many tui chubs as green sunfish. In 1989-90, tui chubs and green sunfish were the most abundant two species in North Fork Willow and Boles creeks, while the catch in Fletcher Creek was primarily tui chub followed by blue chub. Mowitz Creek catch was evenly split between green sunfish and speckled dace. Other species captured by Buettner and Scoppettone (1991) in descending order of abundance were bullheads, bluegills, largemouth bass, pumpkinseed (Lepomis gibbosus), Sacramento perch (Archoplites interruptus), rainbow trout, and brown trout (Salmo trutta). During this study we found the primary two species captured were the nonnative bullheads and green sunfish, and tui chubs were the third most abundant species. Two species that had not been reported for these areas in the previous studies were collected during this study: fathead minnows and black crappie (Pomoxis nigromaculatus). Most fishes present in the system could potentially prey upon larval and small juvenile suckers, whereas, only largemouth bass, bullheads, and trout have high potential to prey on larger juvenile suckers. These species only cooccurred with suckers in Boles and Fletcher creeks during this study. The increase of nonnative species generally indicates a disturbed environment that in this study may be related to the impoundment of water and cattle grazing (Zampella and Bunnell, 1998; Schade and Bonar, 2005).

The effort at the Gerber Reservoir tributaries was limited; however, the CPUE of suckers captured was greater than in Clear Lake tributaries. Suckers were captured at all sampled sites, with the majority of suckers captured in pools within the creeks. Past studies have also found that suckers were primarily found in pools within the creeks (Bureau of Land Management, 2014). Both this study and the 2014 Bureau of Land Management study found the greatest number of suckers in Barnes Valley Creek pools followed by Long Branch Creek pools. The few suckers that were captured in runs during this study were the larger suckers captured in the Gerber Reservoir tributaries. Barnes Valley Creek and Long Branch Creek, but not Lapham Creek, had evidence of bank erosion. During this study, the fewest suckers were captured at Lapham Creek, where habitat was mainly flowing water with pools that were too deep to effectively shock. All suckers in the Gerber Reservoir tributaries were morphologically identified as Klamath largescale suckers, which fits with the habitat preferences observed for suckers in these tributaries during the present study. 
Although the current study occurred in a very dry year with potentially restricted distribution of suckers, due to poor connectivity, the results from this study were similar to the past studies, except that suckers were not collected in the small reservoirs during this study. The previous studies collected Lost River suckers, but this study did not, this difference may have been due to the current study occurring during a dry year. Morphological identifications from the previous studies and this study, indicated that shortnose suckers were captured in the tributaries. However, recent genetic research indicated that suckers morphologically identified as shortnose suckers in the Clear Lake drainage, were determined to be more genetically similar to Klamath largescale suckers in the Upper Klamath Lake drainage (Smith and others 2020). Therefore, we suspect that all fish captured in our study were Klamath largescale, rather than shortnose suckers. The widespread habitat use within the tributaries, by suckers of varying ages, is consistent with identifying the suckers captured in this study as Klamath largescale suckers. The major difference in this study, compared to the previous two studies, is the apparent increase in nonnative species and the lack of Lost River suckers.

\section{Acknowledgments}

Data collection and project implementation were made possible with the help of the U.S. Geological Survey (USGS) Klamath Falls Field Station staff including, Joshua Hargrove, Justin Howard, Rachael Paul-Wilson, and David Smith. Alta Harris (USGS) provided database support.

\section{References Cited}

Andreasen, J.K., 1975, Systematics and status of the family Catostomide in Southern Oregon: PhD Thesis, Oregon State University, $76 \mathrm{p}$.

Banet, N.V., Hewitt, D.A., Dolan-Caret, A., and Harris, A.C., 2021, Spatial and temporal distribution of radio-tagged Lost River (Deltistes luxatus) and shortnose (Chasmistes brevirostris) suckers in Clear Lake Reservoir and associated spawning tributaries, Northern California, 2015-17: U.S. Geological Survey Open-File Report 2021-1061, 36 p., https://doi.org/10.3133/ofr20211061.

Benson, B.B., and Krause, D., Jr., 1980, The concentration and isotopic fractionation of gases dissolved in freshwater in equilibrium with the atmosphere. 1. Oxygen: Limnology and Oceanography, v. 25 , no. 4, p. 662-671, https://doi.org/ 10.4319/lo.1980.25.4.0662.

Benson, B.B., and Krause, D., 1984, The concentration and isotopic fractionation of oxygen dissolved in freshwater and seawater in equilibrium with atmosphere: Limnology and Oceanography, v. 29 , no. 3, p. 620-632, https://doi.org/ 10.4319/lo.1984.29.3.0620.
Bowie, G.L., Mills, W.B., Porcella, D.B., Campbell, C.L., Pagenkopf, J.R., Rupp, G.L., Johnson, K.M., Chan, P.W.H., Gherini, S.A., and Chamberlin, C.E., 1985, Rates, constants, and kinetics formulations in surface water quality modeling: U.S. Environmental Protection Agency Report EPA/600/3-85/040.

Bureau of Land Management, 1992, Draft resource management plan - Environmental impact Statement Klamath Falls Resource Area: Bureau of Land Management, BLM-ORPT-92-34-1792, $442 \mathrm{p}$.

Bureau of Land Management, 2014, Biological assessment regarding the effects of grazing management on the Bureau of Land Management-Lakeview District, Klamath Falls Resource Area: Klamath Falls, Oregon, Bureau of Land Management, Klamath Falls Resource Area, 267 p.

Buettner, M.E., and Scoppettone, G.G., 1991, Distribution and information on the taxonomic status of the shortnose sucker (Chasmistes brevirostris) and Lost River suckers (Deltistes luxatus) in the Klamath River Basin, California: Reno, Nevada, Seattle National Fishery Research Center, 34 p.

Burdick, S.M., Elliott, D.G., Ostberg, C.O., Conway, C.M., Dolan-Caret, A., Hoy, M.S., Feltz, K.P., and Echols, K.R., 2015, Health and condition of endangered juvenile Lost River and shortnose suckers relative to water quality and fish assemblages in Upper Klamath Lake, Oregon, and Clear Lake Reservoir, California: U.S. Geological Survey Open-File Report 2015-1217, 56 p., https://doi.org/10.3133/ ofr20151217.

Burdick, S.M., Ostberg, C.O., Hereford, M.E., and Hoy, M.S., 2016, Juvenile sucker cohort tracking data summary and assessment of monitoring program, 2015: U.S. Geological Survey Open-File Report 2016-1164, 30 p., https://doi.org/ 10.3133/ofr20161164.

Evanno, G., Regnaut, S., and Goudet, J., 2005, Detecting the number of clusters of individuals using the software STRUCTURE—A simulation study: Molecular Ecology, v. 14 , no. 8, p. 2611-2620, https://doi.org/10.1111/j.1365294X.2005.02553.x.

Hayes, M.F., and Rasmussen, J., 2017, Evaluation of endangered lakesucker rearing in tributaries to Upper Klamath Lake by use of X-ray imaging: Western North American Naturalist, v. 77, no. 1, p. 130-135, https://doi.org/10.3398/ 064.077.0115.

Hewitt, D.A., and Hayes, B.S., 2013, Monitoring of adult Lost River and shortnose suckers in Clear Lake Reservoir, California, 2008-2010: U.S. Geological Survey OpenFile Report 2013-1301, 18 p., https://doi.org/10.3133/ ofr20131301. 
Hewitt, D.A., Janney, E.C., Hayes, B.S., and Harris, A.C., 2015, Status and trends of adult Lost River (Deltistes luxatus) and shortnose (Chasmistes brevirostris) sucker populations in Upper Klamath Lake, Oregon, 2014: U.S. Geological Survey Open-File Report 2015-1189, 36 p., https://doi.org/10.3133/ofr20151189.

Hewitt, D.A., Hayes, B.S., Harris, A.C., Janney, E.C., Kelsey, C.M., Perry, R.W., and Burdick, S.M., 2021, Dynamics of endangered sucker populations in Clear Lake Reservoir, California: U.S. Geological Survey Open-File Report 2021-1043, 59 p., https://doi.org/10.3133/ofr20211043.

Hoy, M.S., and Ostberg, C.O., 2015, Development of 20 TaqMan assays differentiating the endangered shortnose and Lost River suckers: Conservation Genetics Resources, v. 7, no. 3, p. 673-676, https://doi.org/10.1007/s12686015-0474-y.

Koch, D.L., and Contreras, G.P., 1973, Preliminary survey of the fishes of the Lost River system including Lower Klamath Lake and Klamath Strait Drain with special reference to the shortnose (Chasmistes brevirostris) and Lost River (Catostomus luxatus) suckers: Reno, Nevada, Desert Research Institute, Center for Water Resources Research, 45 p.

Koch, D.L., Cooper, J.J., Contreras, G.P., and King, V., 1975, Survey of the Fishes of Clear Lake Reservoir Drainage: Reno, Nevada, Desert Research Institute, Center for Water Resources Research, Project Report No. 23, 38 p.

Markle, D.F., Cavalluzzi, M.R., and Simon, D.C., 2005, Morphology and taxonomy of Klamath basin suckers (Catostomidae): Western North American Naturalist, v. 65, no. 4, p. 473-489.

Markle, D.F., Terwilliger, M.R., and Simon, D.C., 2014, Estimates of daily mortality from Neascus trematode in age-0 Shortnose Sucker (Chasmistes brevirostris) and the potential impact of avian predation: Environmental Biology of Fishes, v. 97, no. 2, p. 197-207, https://doi.org/10.1007/ s10641-013-0141-7.

Miller, R.R., and Smith, G.R., 1981, Distribution and evolution of Chasmistes (Pisces Catostomidae) in western North America: Occasional Papers of the Museum of Zoology, University of Michigan, v. 696, p. 1-46.

Moyle, P.B., 2002, Inland fishes of California: Berkeley, California, University of California Press, 517 p.

Perkins, D.L., and Scoppettone, G.G., 1996, Spawning and Migration of Lost River Suckers (Deltistes luxatus) and Shortnose Suckers (Chasmistes brevirostris) in the Clear Lake Drainage, Modoc County, California: National Biological Service Final Report to California Department of Fish and Game, 58 p.
Pritchard, J.K., Stephens, M., and Donnelly, P., 2000, Inference of population structure using multilocus genotype data: Genetics, v. 155, p. 945-959.

Quist, M.C., Pegg, M.A., and DeVries, E.R., 2012, Age and Growth in Zale, A.V., Parrish, D.L., Sutton, T.M., and Sutton, T.M., Fisheries Techniques 3rd ed.: Bethesda, Maryland, American Fisheries Society, p. 223-266.

Saiki, M.K., Monda, D.P., and Bellerud, B.L., 1999, Lethal levels of selected water quality variables to larval and juvenile Lost River and shortnose suckers: Environmental Pollution, v. 105, no. 1, p. 37-44, https://doi.org/10.1016/ S0269-7491(98)00212-7.

Schade, C.B., and Bonar, S.A., 2005, Distribution and abundance of nonnative fishes in streams of the Western United States: North American Journal of Fisheries Management, v. 25, no. 4, p. 1386-1394, https://doi.org/10.1577/ M05-037.1.

Smith, M.J., Von Bargen, J., Smith, C.T., Miller, M.R., Rasmussen, J., and Hewitt, D.A., 2020, Characterization of the genetic structure of four sucker species in the Klamath River-Final report: U.S. Fish and Wildlife Service, Abernathy Fish Technology Center, 32 p.

Sonnevil, G., 1972. Abundance and Distribution of Lost River Sucker (Catostomus luxatus) and the Shortnose Sucker (Chasmistes brevirostris) in Boles and Willow Creek: Modoc County, 18 p.

Sutphin, Z., and Tyler, T., 2016, Entrainment of early life-stage of fish from Clear Lake Reservoir into Lost River: Bureau of Reclamation Report, 25 p.

U.S. Fish and Wildlife Service (USFWS), 1988, Endangered and threatened wildlife and plants - Determination of the Status for the Shortnose Sucker and Lost River Sucker: Federal Register, v. 53, no. 137, p. 27130-27134.

U.S. Fish and Wildlife Service (USFWS), 2012, Endangered and Threatened Wildlife and Plants; Designation of Critical Habitat for Lost River Sucker and Shortnose Sucker: Federal Register, v. 77, no. 238, p. 73740-73768.

U.S. Fish and Wildlife Service (USFWS), 2013, Revised recovery plan for the Lost River Sucker (Deltistes luxatus) and Shortnose Sucker (Chasmistes brevirostris): Sacramento, California, U.S. Fish and Wildlife Service, Pacific Southwest Region, 122 p.

Zampella, R.A., and Bunnell, J.F., 1998, Use of reference-site fish assemblages to assess aquatic degradation in Pinelands streams: Ecological Applications, v. 8, no. 3, p. 645-658, https://doi.org/10.1890/1051-0761(1998)008[0645:UORS FA]2.0.CO;2. 

Publishing support provided by the U.S. Geological Survey Science Publishing Network, Tacoma Publishing Service Center

For more information concerning the research in this report, contact the

Director, Western Fisheries Research Center

U.S. Geological Survey

6505 NE 65th Street

Seattle, Washington 98115-5016

https://www.usgs.gov/centers/wfrc 
뭉.

品

을

$\vec{c}$

$\frac{\frac{2}{\hat{T}}}{\mathrm{~N}}$

5

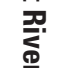

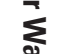

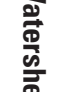

$\frac{0}{0}$

0
0
0
0
0

잉

言

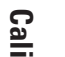

.

응

龺

产

꽁

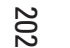

亭 